\title{
COVID-19 Sürecinde Evden Çalışan Annelerde Depresyonu Yordayan Faktörler: İş-Aile Çatışması, Evlilik Uyumu ve Ebeveyn Tükenmişliği*
}

\author{
Understanding The Factors of Depression \\ Among Home-Office Working Mothers During the \\ COVID-19 Outberak: Work-Family Conflict, Dyadic \\ Adjustment and Parenting Burnout
}

Ülkü Parlak**

Selin Karaköse $e^{* * *}$

\begin{abstract}
Özet
Çalışma hayatında yer alan çocuklu kadınların bireysel ve aile yaşantısındaki çoklu rolleri nedeniyle depresyon için risk grubu altında yer aldığı bilinmektedir. İçinde bulunduğumuz COVID-19 pandemisinde evden çalışma düzeniyle birlikte kadınlar için artan bu çoklu roller ile depresyon arasındaki ilişki henüz araştırılmamıştır. Bu çalışmanın amacı, iş-aile çatışması, evlilik uyumu ve ebeveyn tükenmişliğinin depresyon üzerindeki yordayıcı etkisinin klinik olmayan bir örneklem grubunda araştırılmasıdır. Araştırmanın örneklemini evden çalışan, evli ve çocuğu olan 24-55 yaş arası (ORT $=34.27$, SS = 5.88) 495 kadın oluşturmaktadır. Psikososyodemografik Bilgi Formu, Depresyon Anksiyete Stress Ölçeği (DASS-21) Depresyon
\end{abstract}

* Bu yayın, ilk yazarın yüksek lisans tezinden üretilmiştir.

** Uzman Klimik Psikolog, İstanbul, Türkiye. ulkuparlak1@gmail.com, 00000001-9981-5573

*** Dr. Öğr. Üyesi, FMV Işık Üniversitesi, İktisadi İdari ve Sosyal Bilimler Fakültesi, Psikloji Bölümü, İstanbul, Türkiye. selin.karakose@isikun.edu. tr, 0000-0001-8629-4422

Başvuru: 13.09.2021

Kabul: 27.10.2021

DOI: $10.21798 /$ kadem. 2022.56
This work is licensed under the Creative Commons Attribution 4.0 International License.

Cite this article as: Parlak, Ü. ve Karaköse, S. (2021). COVID-19 Sürecinde Evden Çalışan Annelerde Depresyonu Yordayan Faktörler: Iş-Aile Çatışması, Evlilik Uyumu ve Ebeveyn Tükenmişliği, Kadem Kadın Araștırmaları Dergisi, Vol. 7, No. 2: $149-189$ 
Alt Boyutu, Yenilenmiş Çift Uyum Ölçeği (YÇUÖ), İş-Aile Çatışması Ölçeği (İAÇÖ) ve Ebeveyn Tükenmişlik Değerlendirmesi’yle (ABT) oluşan anket bataryası çevrimiçi olarak sunulmuştur. Çoklu hiyerarşik regresyon analizi sonuçlarına göre, iş-aile çatışması, evlilik uyumu ve ebeveyn tükenmişliği değişkenlerinin depresyonu istatistiksel olarak anlamlı ve birbirine benzer güç düzeyinde yordadığı bulunmuştur. Çalışmada elde edilen bulguların, çalışan kadınlarda depresyonla müdahale programlarında pratik ve teorik açılardan fayda sağlayacağı düşünülmektedir.

Anahtar Sözcükler: iş-aile çatışması, evlilik uyumu, ebeveyn tükenmişliği, depresyon, COVID-19 pandemisi ve evden çalışma

\begin{abstract}
It is known that due to their multiple roles in their personal and family lives, working women with children are at risk for depression. The relationship between depression and these multiple roles, which has increased with the pattern of working from home during the COVID-19 pandemic, has not yet been investigated. The purpose of this study is to investigate the predictive roles of work-family conflict, dyadic adjustment, and parental burnout on depression in a non-clinical sample. The sample of the study consists of 495 women who are working from home, are married with children, and are between the ages of $24-55(M=34.27, S D=5.88)$. The questionnaire battery that has been presented online includes Psycho-Social Demographic Information Form, Depression Subscale of Depression Anxiety Stress Scale Short Form (DASS-21), Revised Dyadic Adjustment Scale (RDAS), Work-Family Conflict Scale (WFC), and Parental Burnout Assessment (PBA). According to the results of multiple hierarchical regression analysis, it has been found that work-family conflict, dyadic adjustment, and parental burnout predict depression at a significant level with similar effect size. It is thought that the findings contained in the study will provide practical and theoretical benefits in intervention programs related to depression among women.
\end{abstract}

Keywords: parental burnout, work-family conflict, dyadic adjustment, depression, COVID-19 pandemic and home-office working

\title{
Extended Abstract
}

Depression is a mood disorder that is characterized by feelings of helplessness, hopelessness, and sadness (APA, 2013). It can greatly reduce people's quality of life and affects over 264 million people 
around the world (James et al., 2018). Detection of the predictive factors of depression, which is a public health problem, is important for prevention studies.

Studies have shown that women have a much higher risk of depression than men (Kessler, 2003; Tam et al., 2018; Wolanin, Hong, Marks, Panchoo \& Gross, 2016). Among women, it is also known that being married is a predictor of depression (Romanoski et al., 1992). The reason married women are more prone to depression than single women is explained mostly by their responsibilities regarding home and children. Another factor that adds to women's situation of being more inclined to depression is having children (Evenson and Simon, 2005; Perren, Wyl, Bürgin, Simoni \& Klitzing, 2005). Apart from being married, working and having children, it is known that working is another risk factor for depression, and the depression level of working women is higher than that of nonworking women (Revati \& Yogesh, 2012). In summary, in the light of the information provided in the literature, being a woman, being married, being a parent, and working are risk factors for depression in women.

During the COVID-19 pandemic, considering the increase in the number of individuals working from home (Gaudecker, Radost, Lena, Bettina \& Christian, 2020) and the fact that home as a working space is associated with work-family conflicts (Buzzanell, 2004), along with the increase in the problems experienced by couples due to the pandemic (Pietromonaco \& Overall, 2020), it is important to evaluate these risk factors for depression as specific to the process.

This study aims to investigate the relationship between work-family conflict, dyadic adjustment, and parental burnout with depression in married mothers who work during the COVID-19 pandemic and to contribute to the development of pandemic-specific intervention studies.

\section{Giriş}

Depresyon, Amerikan Psikiyatri Birliği (American Psychiatric Association [APA]) tarafından derin üzüntü, zevk alamama ve çaresizlik duygularıyla karakterize olmuş bir duygudurum bozukluğu olarak tanımlanmaktadır (APA, 2013). Pek çok psikiyatrik tanının açıklanmasında kullanılan Biyopsikososyal Model, depresyonun 
kaynağının biyoloji, sosyal ve psikolojik faktörlerle ilişkili olduğunu söyleyerek bütüncül bir yapı sunmaktadır (Kinderman, 2005). Biyopsikososyal model, özellikle son yıllarda kabul edilen ve geçerliliği kanıtlanmış bir model olarak bilinmektedir (Kinderman, Schwannauer, Pontin ve Tai, 2013).

Depresyon ve cinsiyet arasındaki ilişkinin araştırıldığı epidemiyolojik ve meta analiz çalışmaları (Örn. Kessler, 2003; Tam vd., 2018) erkeklere kıyasla, kadınlarda depresyonun çok daha fazla olduğuna işaret ederken, bu farkın sadece klinik örnekleme özgü değil, genel popülasyon için de benzer olduğuna dikkat çekmektedir (Busch, Maske, Ryl, Schlack ve Hapke, 2013; Kockler ve Heun, 2002; Moscato vd., 1997; Muhtz, Zyriax, Klähn, Windler ve Otte, 2009; Rhee vd., 2014). Bir başka ifadeyle, kadın olmak hem klinik hem klinik olmayan gruplarda depresyon için önemli bir risk faktörüdür. Bu farka yönelik açıklamalardan biri, biyolojik faktörlerin rolüne işaret etmektedir. Yaşam boyu gelişim göz önüne alındığında, okul çağında depresyon ile cinsiyet arasinda bir fark bulunmazken (Nolen-Hoeksema ve Hilt, 2009), ergenlik çağında bu farkın ortaya çıktığı ve en sık doğurganlık yaşlarında görüldüğü (Noble, 2005) dikkat çekmektedir. Bu farkın gelişimsel dönemler ve hormonel değişimlere işaret etmesi, depresyonda biyolojik rolün önemine yönelik açıklamalar sunsa da günümüzdeki hâkim olan biyopsikososyal yaklaşım kapsamında biyolojik açıklamalar tek başına yeterli görülmemektedir. Biyopsikososyal yaklaşım kapsamında, kadın olmanın depresyon için bir risk faktörü olmasının sebepleri değerlendirilirken, biyolojik faktörlerle beraber sosyal faktörlerin de göz önünde bulundurulması gereklidir (Kessler, 2003).

Kadınlar için depresyona dair sosyal faktörleri değerlendiren çalışmaların odaklandığı değişkenlerden biri çalışma durumudur. Çalışma durumu hakkındaki araştırmalar karışık sonuçlar vermektedir. Çalışan kadınların daha fazla depresif semptom yaşadığını söyleyen araştırmalar mevcutken (Örn. Revati ve Yogesh, 2012; Özgür, Atan ve Ardahan, 2012), bunun tam tersini iddia eden ve çalışmayan kadınların daha fazla depresyon deneyimlediğini öne süren 
araştırmalar da bulunmaktadır (Örn. Caetano, Vaeth, Mills ve Canino, 2016; Dougé, Lehman ve McCall-Hosenfeld, 2014). Her çalışan ya da çalışmayan kadında depresyon görülmediğinin bilincinde olarak, kişilerin çalışıp çalışmama durumundan bağımsız bir şekilde, çalışma durumlarıyla ilişkilendirilebilecek başka bir faktörün varlığı düşünülmelidir. Buna bağlı olarak, kadınlardaki çalışma ve depresyon ilişkisini açıklamak için iş-aile çatışması kavramı öne sürülmüştür. İş-aile çatışması, kişinin meslekî ve ailesel sorumluluklarının birbirine karışmasıyla deneyimlenen rol karmaşası olarak görülmektedir (Greenhaus ve Beutell, 1985). İş-aile çatışması birçok farklı alanda olumsuz deneyimlere neden olmaktadır. Bu alanlardan biri kişinin iş hayatıdır ve yapılan araştırmalara göre, iş-aile çatışması yaşandığı durumda kişinin işi bırakma ihtimalinin artması, işten aldığı tatminin ve terfi alma ihtimalinin azalması, kendini işe daha az vermesi ve çalıştığı kuruma karşı daha az bağlı hissetmesi gibi sonuçlar ortaya çıkmaktadır (Allen, Herst, Bruck ve Sutton, 2000; Anderson, Coffey ve Byerly, 2002; Grandey ve Cropanzano, 1999; White, Hill, McGovern, Mills ve Smeaton, 2003). Öte yandan, bireylerin yaşadığı iş-aile çatışması arttıkça evliliklerine dair hissettikleri uyumun azaldığı görülmüştür (Higgins, Duxbury ve Irving, 1992; Wu, Chang ve Zhuang, 2010). Ayrıca, artan iş-aile çatışmasının kişinin fiziksel rahatsızlıklarını arttırabileceği gibi (Netemeyer, Boles ve McMurrian, 1996), depresyonla da yakından ilişkili olduğu bilinmektedir (Du Prel ve Peter, 2015; Hao, Wang, Liu, Wu ve Wu, 2016; McTernan, Dollard, Tuckey ve Vandenberg, 2016; Obidoa, Reeves, Warren, Reisine ve Cherniack, 2011). Bu kapsamda çalışan kadınlarda depresyona sebep olan faktörlerden birinin iş-aile çatışması olduğu ve bunu da evli ve çocuğu olan kadınların sıklıkla deneyimledikleri bilinmektedir (Akçınar, 2020).

Kadınlar için çalışma durumuna ek olarak, sosyal faktörlerden medeni durumun depresyon için belirleyici olduğu ve evli olmanın depresyon için bir risk faktörü olduğu yapılan araştırma bulgularında dikkat çekmektedir. Bekarlara kıyasla, evli olan kişilerin duygudurum bozukluğuna sahip olma ihtimalinin neredeyse üç kat fazla olduğu bilinmektedir (Kaygısız ve Alkın, 1999). Klinik olmayan 
örneklemde yapılan bir çalışma, evliliğinden memnun olan evli bireyler için depresif semptomların yaygınlığının oranı \%14 iken, evliliğinden memnun olmayan evli bireyler için bu oranın \%42 olduğuna dikkat çekmektedir (St John ve Montgomery, 2009). Bir başka ifadeyle, evli olmak depresyon için koruyucu bir faktör olabileceği gibi, bir risk faktörü olarak da görülmektedir.

Evlilik memnuniyetsizliği ile depresyon arasındaki pozitif yönlü ilişki (Whisman, 2007), evlilik uyumu kapsamında değerlendirilmektedir. Alanyazında evlilik uyumu, evlilikten alınan tatmin, evlilikteki mutluluk ya da evliliğin kalitesi kavramları birbirinin yerine geçecek şekilde kullanılmaktadır (Kendrick ve Drentea, 2016). Evlilik uyumu için yapılan çalışmalar kadınlarda evlilik uyumunun, erkeklere göre daha düşük olduğuna dikkat çekmektedir (Cirhinlioglu, Tepe ve Cirhinlioglu, 2016; Fowers, 1991) ve bu fark kadınların evlilikle birlikte artan iş yükleriyle ilişkilendirilmektedir. Hem anne hem baba için çocuk sahibi olmanın önemli bir geçiş olduğu ve bu nedenle stresle ilişkili olarak ebeveynlerin depresif semptomlar göstermeleri olası olarak değerlendirilmektedir (Perren, Wyl, Bürgin, Simoni ve Klitzing, 2005). Ancak, ebeveynlik ve depresyon arasındaki ilişki cinsiyet bağlamında değerlendirildiğinde, depresyonun kadınlarda daha yaygın görüldüğü bulgusuna paralel şekilde, kadın ebeveynlerde depresyona daha sık rastlandığı dikkat çekmektedir. Kadınların doğum yaptıktan sonra yaklaşık yarısının depresif semptomlar gösterdiği ve neredeyse \%10-20 gibi bir oranın da doğum sonrası depresyonu yaşadığı bilinmektedir (Miller, 2002). Çocuğu olan anneler ve babalar arasındaki fark konusunda, doğumun ilk haftası ve ikinci ayındaki depresif semptomları inceleyen bir çalışmada kadınlarda iki zaman diliminde de depresyona meyilliliğin erkeklere göre daha yüksek olduğu görülmüştür (Edhborg, Matthiesen, Lundh ve Widström, 2005). Ülkemizde yapılan bir çalışma da ebeveyn olan kadınların erkeklerle kıyaslandığında daha yüksek depresif semptomlar gösterdiğini bulmuştur (Serhan, Ege, Ayrancı ve Kosgeroglu, 2012). Bir başka ifadeyle, tıpkı depresyon ve evlilik uyumunda olduğu gibi çocuk sahibi kadınlarda depresyonun daha yaygın olduğu 
görülmektedir. Cinsiyet rolleri adı altında, toplumda kadınların erkeklere göre daha fazla sıklıkta bakım veren rolü üstlendiği düşünülmekte ve çocuk bakımının daha çok kadınlarla ilişkilendirildiği görülmektedir (Miller, 2003). Tüm bu bilgiler dâhilinde, biyopsikososyal model kapsamında aile ilişkilerinin sosyal bir faktör olarak değerlendirilebileceği anlaşılmaktadır. Bu bağlamda evlilik uyumu bu çalışmada depresyonun bütüncül yaklaşımında sosyal bir faktör olarak modele dâhil edilmiştir.

Çocuk sahibi olmak ve depresyon arasındaki bu ilişki, bu rolün getirmiş olduğu yükün bir sonucu olan ebeveyn tükenmişliğiyle ilişkili görülmektedir. Ebeveyn tükenmişliği, ebeveynliğin getirdiği çeşitli stres faktörlerine sürekli maruz kalmanın sebep olduğu özel bir sendrom olarak tanımlanmaktadır ve ebeveynlik rolünün yaratabileceği bıkkınlık, mesafelilik, yetersizlik algısı gibi faktörlerle ilişkilidir (Mikolajczak, Brianda, Avalosse ve Roskam, 2018). Ebeveyn tükenmişliğinin kişinin partneriyle olan sorunlarının sıklığını ve şiddetini arttırması dışında (Mikolajczak vd., 2018), depresyon başta olmak üzere psikolojik ve fiziksel rahatsızlıklara yol açabileceği vurgulanmaktadır (Creedy, Sidebotham, Gamble, Pallant ve Fenwick, 2017). Yapılan çalışmalar benzer şekilde, annelerin yaşadığı ebeveynlik tükenmişlik seviyesi arttıkça depresyon ve anksiyete seviyelerinin de arttığını göstermektedir (Lebert-Charron, Dorard, Boujut ve Wendland, 2018). Bu kapsamda, ebeveyn tükenmişliğinin psikolojik bir faktör ve biyopsiksosyal model kapsamında depresyon için bir etken olduğu görülmektedir.

Bununla beraber, depresyonla ilişkili olduğu vurgulanan ve yukarıda açıklanan tüm kavramlar, içinde bulunduğumuz pandemi koşulları ışığında yorumlanmalıdır. Çin’in Wuhan kentinde 2019 yılında ortaya çıkan ve yüksek ateş, öksürük, solunum güçlüğü, tat/ koku kaybı gibi semptomlarla karakterize olmuş COVID-19 virüsü, Dünya Sağlık Örgütü tarafından "pandemi” ilan edilmesine ve bütün dünyada sağllk, ekonomi, iletişim ve iş düzeni gibi birçok meseleyi olduğundan farklı şekillerde ele almamıza sebep olmuştur (“Coronavirus", 2021). Türkiye'de de bu süreç aynı şekilde işlemiş 
ve ilk vakanın açıklandığı 11 Mart tarihinden itibaren sosyal mesafeyi arttırmak ve bulaş oranını azaltmak için alınan kararlarla sokağa çıkma kısıtlamaları, zorunlu maske kullanımı, eğitime ara verme, esnaf iş yerlerinin kapatılması ve kapatılmayan iş yerlerinde home-office çalışma düzenine geçilmesi gibi büyük değişiklikler yaşanmıştır.

Salgın sürecinde uyum sağlanması gereken büyük değişikliklerden biri kişilerin evden çalışmaya başlaması olmuştur. Pandemi öncesinde kişilerin \%9'undan azı evden çalışırken, pandemi esnasında bu oranın kadınlar için \%52, erkekler için \%42 olduğu görülmüştür (Farré, Fawaz, Gonzales ve Graves, 2020). COVID-19'dan korunma amaçlı uygulanan evden çalışma hâlinin firmaların tasarrufuna ve çalışanların daha esnek olabilmesine yarar sağlayabileceğinin (Brownson, 2004) yanında çeşitli olumsuz etkilere de yol açabileceği söylenmektedir. Bu etkilerden bir tanesi, kişinin ailesi ve işi arasındaki sınırın kaybolması olarak görülmektedir. Çalışan kişiler işlerini eve getirdiğinde ya da genel olarak evden çalıştıklarında aile ve iş arasındaki sınırın bulanıklaştığı, farklı konulardaki görevlerin birbirinin içine geçtiği ve bu görevlerin yapılmasında zorluk yaşandığı görülmüştür (Sullivan, 2000). Evden çalışma deneyimi kişiden kişiye değişmektedir. Evden çalışırken kendine zaman ayırabilenlerin çocuksuz kişiler, iş-aile çatışmasını en çok deneyimleyenlerin ise küçük çocuğu olan anneler olduğu görülmüştür (Crosbie ve Moore, 2004). Cinsiyet açısından incelendiğinde anneler ve babalar arasında da farklar görülmektedir. COVID-19 sürecinde yapılan bir çalışmaya göre, ailede hem annenin hem de babanın çalışması durumunda dahi, babalarla kıyaslandığında annelerin çocuk bakımına 3 kat daha fazla zaman ayırdığı görülmüsstür (Arntz, Ben Yahmed ve Berlingieri, 2020). Çocuk bakımının dışında, evden çalışma durumunda iş-aile dengesini araştıran niteliksel bir çalışmada, katılımcıların yarısından fazlası evden çalışan kişilerin ofisten çalışan kişilere göre daha uzun saatler çalıştığını, bunun da partnerleriyle sorun yarattığını söylemiştir (Crosbie ve Moore, 2004). Özetlenen tüm bu sonuçlar ışığında, evden çalışma sürecinin çiftler arasında sorun yaratabileceği, iş-aile çatışmasını arttırabileceği ve erkeklerle 
kıyaslandığında bu durumdan daha çok çalışan evli ve çocuklu kadınların muzdarip olduğu görülmektedir.

Özetle, pandemi öncesi yapılan çalışmalar, evden çalışan kadınların iş-aile çatışmasını deneyimlediklerine işaret ederken (Buzzanell, 2004; Roehling, Moen ve Batt, 2003), içinde olduğumuz salgın dolayısıyla çalışan kişilerin evden çalışma saatlerinin arttığı bilinmektedir (Gaudecker, Radost, Lena, Bettina ve Christian, 2020). İş-aile çatışması yaşamanın, kadınların ruh sağlığı problemlerinde belirleyici bir faktör olduğu bilgisinden yola çıkarak (Susi, Kumar ve Jothikumar, 2019), pandemi koşullarında evden çalışmanın iş-aile çatışmasını ve ruh sağlığını nasıl etkilediği araştırılması gereken önemli bir olgudur. Öte yandan, COVID-19 pandemisi sürecinde evlerde geçirilen vaktin artmasının evlilik ilişkisinde çeşitli problemlere neden olabileceği ön görülmektedir (Pietromonaco ve Overall, 2020). Evlilik uyumunun pandemi öncesinde de ruh sağlığıyla yakından ilişkili olduğu bilgisi dâhilinde (Mikolajczak vd., 2018), pandemi sürecinde evlilik uyumunun rolünün açıklığa kavuşturulması önem taşımaktadır. Ailede küçük çocuğa sahip olmanın evlilik uyumunu olumsuz etkilemesi dışında, ebeveynlik tükenmişliğine neden olarak ebeveyn olmanın depresyon için risk teşkil ettiği bilinmektedir (Evenson ve Simon, 2005). Pandemi şartlarında neredeyse 1 yıldır, evden çalışan evli ve çocuk sahibi kadınların çocuk bakımı ve ev işleri konusunda destek alamadıkları ya da kısıtlı destek aldıkları göz önüne alındığında, çocukların okula devam etme imkânları kısıtlı olurken, kendilerinin de evden çalışma sorumluluklarıyla ebeveyn tükenmişliği için riskli hâle geldiği düşünülmektedir. Tıpkı iş-aile çatışması ve evlilik uyumu gibi, ebeveynlik tükenmişliği de depresyon için risk teşkil eden diğer bir faktördür (Roskam, Raes ve Mikolajczak, 2017).

Erkeklerle kıyaslandığında kadınların çocuk bakımı da dâhil olmak üzere ev işlerinin çoğundan bir şekilde sorumlu oldukları düşünüldüğü için özellikle çalışan kadınlar adına bu cinsiyet eşitsizliğinin pandemi döneminde de anlamlı ve depresyonla ilişkisi olduğu düşünülmektedir (Almeida, Shrestha, Stojanac ve Miller, 
2020). Kadınların hem pandemi öncesinde hem pandemi döneminde depresyon için risk grubu olmasına ek olarak, pandemi sürecinde yaşadıkları fiziksel ve psikolojik etkinin erkeklerle kıyaslandığında daha uzun dönemli olabileceği öngörüldüğü için pandemi sonrası süreç için de risk taşımaktalardır (Bucciarelli vd., 2021). $\mathrm{Bu}$ bilgiler dâhilinde COVID-19 pandemisinde evden çalışan kadınlarda depresyonla ilişkili faktörlerin belirlenmesi, ilgili faktörlerin tespitinin yapılması ve çalışmalarla ortaya konulması ileride oluşturulacak müdahale programları için önem taşımaktadır. Ülkemizde COVID-19 pandemisi kapsamında, COVID-19 tanısı alan ve almayan bireylerin önleyici sağlık davranışlarının incelenmesi (Karaköse ve Akçınar, 2020), özel sektör ve kamu çalışanlarının kaygı düzeylerinin karşılaştırılması (Çiçek ve Almalı, 2020) ve 65 yaş üzeri bireyler için değerlendirmeler (Gencer, 2020) başta olmak üzere klinik psikoloji alanında farklı örneklem gruplarıyla çalışmalar yürütülmüş olsa da, COVID-19 pandemisinde evden çalışan ve çocuğu olan kadınlarda depresyonla yakından ilişkili olan iş-aile çatışması, evlilik uyumu ve ebeveyn tükenmişliği kavramlarının henüz bir arada incelenmediği görülmüştür. Oysa, depresyon için risk grubu olarak belirlenen kadınlarda, depresyonla ilgili bu faktörlerin rolünün belirlenmesi, sorunun tespiti ve olası müdahale programların geliştirilmesi için önem arz etmektedir. Bu çalışmanın amacı COVID-19 pandemisinde, evden çalışan ve çocuğu olan evli kadınlarda evlilik uyumu, iş-aile çatışması ve ebeveyn tükenmişliğinin depresyon üzerindeki yordayıcı rolünün araştırılmasıdır. Bu amaca ek olarak, COVID-19 pandemisinde evden çalışmanın kadınlar için iş-aile çatışmasına neden olması (Buzzanell, 2004) ve çocuk yaş grubunun (Crosbie ve Moore, 2004), bu çatışmada önemli bir faktör olduğu bilgileri göz önüne alınarak, iş-aile çatışması puanlarının evden çalışma koşuluna (tamamen evden ya da hem evden hem ofisten çalışma) ve çocuk yaşına göre farklılık gösterip göstermediğinin incelenmesi hedeflenmiştir. Bu amaçlar doğrultusunda, evli ve çalışan kadınlarda iş-aile çatışmas1, evlilik uyumu ve ebeveyn tükenmişliğinin depresyonu yordaması ve iş-aile çatışma puanlarının tam zamanlı olarak evden çalışan 
kadınlarla 0-2 yaş arası çocuğu olan annelerin daha yüksek olması beklenmektedir.

\section{Araştırmanın Yöntemi}

Bu bölümde sırasıyla çalışmaya katılan katılımcılara ait bilgilere, araştırmanın işlemine ve verilerin analizine yer verilecektir.

\section{Katılımcılar}

Bu çalışmanın örneklemini seçkisiz olmayan örnekleme yöntemlerinden biri olan uygun örnekleme kapsamında, araştırmacının sosyal kaynakları aracılığıyla yapılan duyurular ile kartopu örneklem yöntemiyle ulaşılan ve çalışmaya gönüllü olarak katılmayı kabul eden Türkiye'de yaşayan, 24-55 yaş arası (Ort $=35.27$, $\mathrm{SS}=5.88) 495$ kadın oluşturmaktadır. Çalışmaya katılmak için (1) evli olmak, (2) pandemi nedeniyle tam zamanlı evden çalışma düzeninde çalışıyor olmak ya da pandemi nedeniyle bazen evden bazen ofisten çalışıyor olmak, (3) 18 yaş altında çocuğa sahip olmak içleme kriterleri belirlenmiştir. Çalışmada, pandemi kapsamında düzenli olarak ofisten çalışmak ve Türkiye'de yaşamamak dışlama kriterleri olarak belirlenmiştir. Ülkemizde şehirlerin farklı coğrafi ve sosyoekonomik düzeyleri göz önüne alınarak, tüm bölgelerden veri toplanan bu çalışmada, katılımcıların yarısına yakını $(\% 42,3)$ en yüksek nüfusa sahip İstanbul'da yaşarken, kalan kısmı $(\% 57,7)$ Türkiye'nin diğer illerinde yaşamaktadır. Katılımcıların yarısı $(\% 51,7)$ gelir düzeyini orta olarak algılarken, diğerleri (\%48.3) alt ve yüksek olarak değerlendirmiştir. Katılımcılara ait bilgiler Tablo 1'de sunulmuştur. 
Tablo 1. Araştırmaya Katılan Kişilerin Sosyodemografik ve

Diğer Veriler Açısından Sayısal ve Yüzdelik Dağılımları

\begin{tabular}{|c|c|c|c|}
\hline $\mathrm{N}=495$ & & $\mathbf{N}$ & $\%$ \\
\hline Çalışma Şekli & $\begin{array}{l}\text { Pandemi dolayısıyla } \\
\text { tam zamanlı olarak } \\
\text { evden çalışıyorum }\end{array}$ & 293 & 59.2 \\
\hline & $\begin{array}{l}\text { Bazı zamanlar evden } \\
\text { bazı zamanlar ofisten } \\
\text { çalışıyorum }\end{array}$ & 202 & 40.2 \\
\hline Çocuk Sayısı & 1 & 325 & 65.7 \\
\hline & 2 & 147 & 29.7 \\
\hline & 3 & 21 & 4.2 \\
\hline & 4 ve fazlası & 2 & 0.4 \\
\hline $\begin{array}{l}\text { Çocukların } \\
\text { Yaşına }\end{array}$ & $\begin{array}{l}\text { 0-2 yaşında çocuğu } \\
\text { olan anneler }\end{array}$ & 112 & 22.6 \\
\hline & $\begin{array}{l}\text { 3-5 yaşında çocuğu } \\
\text { olan anneler }\end{array}$ & 159 & 32.1 \\
\hline & $\begin{array}{l}\text { 6-12 yaşında çocuğu } \\
\text { olan anneler }\end{array}$ & 166 & 33.5 \\
\hline & $\begin{array}{l}\text { 13-18 yaşında çocuğu } \\
\text { olan anneler }\end{array}$ & 58 & 11.7 \\
\hline Algilanan & Düşük \& düşük-orta & 82 & 16.5 \\
\hline & Orta & 256 & 51.7 \\
\hline & Orta-yüksek \& yüksek & 157 & 31.7 \\
\hline Mezun Olunan & Lise & 23 & 4.6 \\
\hline & Ön lisans & 3 & 0.6 \\
\hline & Lisans & 316 & 63.8 \\
\hline & Yüksek Lisans & 129 & 26.1 \\
\hline & Doktora ve üzeri & 24 & 4.8 \\
\hline Yaşanılan Yer & İstanbul & 211 & 42.3 \\
\hline & $\begin{array}{l}\text { Marmara Bölgesi (İs- } \\
\text { tanbul Hariç) }\end{array}$ & 52 & 10.8 \\
\hline & İç Anadolu Bölgesi & 82 & 16.5 \\
\hline & Ege Bölgesi & 47 & 9.6 \\
\hline & Akdeniz Bölgesi & 36 & 7.3 \\
\hline
\end{tabular}




\begin{tabular}{|c|c|c|c|c|c|c|}
\hline & Karadeniz Bölgesi & 36 & 7.3 & & & \\
\hline & Doğu Anadolu Bölgesi & 16 & 3.2 & & & \\
\hline & $\begin{array}{l}\text { Güneydoğu Anadolu } \\
\text { Bölgesi }\end{array}$ & 15 & 3 & & & \\
\hline \multirow[t]{5}{*}{ Eş ile Tanışma } & İ̧̧-okul aracılığıyla & 216 & 43.6 & & & \\
\hline & Arkadaş aracıllğıyla & 172 & 34.7 & & & \\
\hline & Aile aracılığıyla & 47 & 9.5 & & & \\
\hline & İnternet aracılığıyla & 45 & 9.1 & & & \\
\hline & Diğer (Kurs, konser...) & 15 & 3.0 & & & \\
\hline \multirow{2}{*}{$\begin{array}{l}\text { Psikiyatrik } \\
\text { Tanı }\end{array}$} & Evet & 70 & 14.1 & & & \\
\hline & Hayır & 425 & 85.9 & & & \\
\hline \multirow[t]{7}{*}{ Tanı İsmi } & Anksiyete Bozuklukları & 32 & 45.7 & & & \\
\hline & $\begin{array}{l}\text { Duygudurum Bozuk- } \\
\text { lukları }\end{array}$ & 25 & 35.7 & & & \\
\hline & $\begin{array}{l}\text { OKB ve İlişkili Bozuk- } \\
\text { luklar }\end{array}$ & 5 & 7.1 & & & \\
\hline & $\begin{array}{l}\text { Travma ve İlişkili } \\
\text { Bozukluklar }\end{array}$ & 3 & 4.3 & & & \\
\hline & Yeme Bozuklukları & 1 & 1.4 & & & \\
\hline & $\begin{array}{l}\text { Nörobilişsel Bozuk- } \\
\text { luklar }\end{array}$ & 1 & 1.4 & & & \\
\hline & Diğer* & 3 & 4.3 & & & \\
\hline \multirow{3}{*}{$\begin{array}{l}\text { Psikiyatrik } \\
\text { İlaç Kullanımı }\end{array}$} & Evet & 32 & 6.5 & & & \\
\hline & Hayır & 463 & 93.5 & & & \\
\hline & & & & Ortalama & Min-Maks & SS \\
\hline Yaş & & & & 35.27 & $24-55$ & 5.88 \\
\hline $\begin{array}{l}\text { Çalışma Saat- } \\
\text { leri (haftalık) }\end{array}$ & & & & 28.94 & $2-85$ & 15.45 \\
\hline Aylık Kazanç & & & & 5.881 & $500-50.000$ & 3.8 \\
\hline $\begin{array}{l}\text { Ailenin } \\
\text { Kazancı }\end{array}$ & & & & 12.830 & $1.200-70.000$ & 8.09 \\
\hline Evlilik Yılı & & & & 9.15 & $1-29$ & 5.66 \\
\hline $\begin{array}{l}\text { Çocukların } \\
\text { Yaşı }\end{array}$ & & & & 5.43 & 4 aylık-18 yaş & 4.47 \\
\hline
\end{tabular}

* Psikiyatrik Tanı sorusunda diğer cevabı veren katılımcılar tanılarını bilmediklerini yazmışlardır. 


\section{Veri Toplama Araçları}

\section{Bilgilendirilmiş Onam Formu}

Araştırmacılar tarafindan hazırlanan formda, çalışmanın amacına ek olarak, araştırmanın süresi, katılımın gönüllülük esasına dayandığı, katılmama ve devam etmeme hakları içeren bilgiler dışında, katılma durumunda veri setinin bilimsel araştırmalarda kullanılacağı belirtilmiştir. Araştırmacıların iletişim bilgilerinin sunulmasının ardından, gönüllü olarak katılmayı kabul eden katılımcıların bunu içeren ifadeyi işaretlemeleri istenmiştir.

\section{Psikososyodemografik Bilgi Formu}

Araştırmacılar tarafından hazırlanan bu formda, katılımcıların sosyodemografik özellikleri hakkında bilgi edinmek için yaş, meslek, çalışma durumu, haftalık çalışma süresi, pandemide çalışma koşulu, eğitim durumu, gelir bilgisi ve psikiyatrik tanı geçmişine ek olarak, evliliğine yönelik bilgi almak adına, ne kadar süredir evli olduğu, eşiyle ne şekilde tanıştığı ve çocuk sayısı ile yaşları sorulmuştur.

\section{İş-Aile Çatışması Ölçeği}

Kişilerin ailesel ve işsel sorumlulukları arasında ne derece çatışma yaşadığını ölçmek için Netemeyer, Boles ve McMurrian (1996) tarafından tasarlanan İş-Aile Çatışması Ölçeği, 10 maddeden ve 2 alt boyuttan (aile yüklerinin işi bölmesi / aile-iş çatışması, iş yüklerinin aileyi bölmesi / iş-aile çatışması) oluşmaktadır. Öz bildirime dayalı olan ölçekte, kişilerin iş ve ailesel sorumlulukları arasındaki dengeyi ne derece sağlayabildiklerine dair sorular sorulmakta ve ifadelerin kendilerine uygunluklarını 5'li Likert Skalası üzerinden ( $1=$ Kesinlikle katılmıyorum, $5=$ Kesinlikle katılıyorum) değerlendirmeleri istenmektedir. Toplam puan alınmayan ölçekte, alt boyutlardan alınan puan düzeyi ile kişinin yaşadığı çatışma doğru orantılıdır. Ölçeğin Türkiye uyarlaması Aycan ve Eskin (2005) tarafından yapılmış ve aile-iş çatışması alt boyutu için iç tutarlık katsayı değerleri .89, iş-aile çatışması için ise .90 olarak bulunarak 
güçlü psikometrik özellikleriyle alanyazında kullanıma uygun bulunmuştur.

\section{Yenilenmiş Çift Uyum Ölçeği (YÇUÖ)}

Spanier (1976) tarafindan çiftlerin birbiriyle ne derece uyumlu olduklarını ölçmek amacıyla tasarlanan ölçeğin orijinali, 32 madde ve 4 farklı boyuttan (çift doyumu, görüş birliği, uzlaşma, duygusal ifade) oluşmaktadır. Busby, Crane, Larson ve Christensen (1995) tarafından kısaltılıp 14 maddeye ve 3 farklı boyuta (çift doyumu, görüş birliği, uzlaşma) indirilerek kısa formu oluşturulan ölçeğin iç tutarlılık katsayısı alt ölçekler için sırasıyla .81, .85, .80 olarak bildirilmiştir. Öz bildirime dayalı ölçek, kişilerin partneriyle olan ilişkilerine dair çeşitli alanları kapsayacak şekilde soruları içermekte ve kişilerden 5'li Likert Skalası üzerinden (1=hiçbir zaman, 5=çoğu zaman) değerlendirilmesini istemektedir.

Ölçeğin 14 maddeden oluşan kısa versiyon çalışması ülkemizde Gündoğdu (2007) tarafından yapılmış ve alt ölçekler için iç tutarlık katsayıları çift doyumu, görüş birliği, uzlaşma için sırasıyla .80, .74, .80 olarak bulunmuştur. Ölçek toplam puan kullanımı sunması dışında, alt ölçeklerin kendi içlerinde aldığı puan kullanımına olanak tanımaktadır ve bu çalışmada alt ölçekler kullanılmıştır.

\section{Ebeveyn Tükenmişlik Değerlendirmesi (ABT)}

Roskam ve diğerleri (2018) tarafından ebeveynlerin çocuklarıyla alakalı olan rollerine bağlı olarak ne derece tükenmişlik yaşadığını ölçmek için tasarlanan ölçeğin orijinali, 23 madde ve duygusal tükenmişlik, eskiden olunan ebeveyne zıtlık, bıkkınlık durumu ve duygusal mesafe olmak üzere 4 alt boyuttan oluşmaktadır. Alt ölçeklerin iç tutarlık katsayıları sırasıyla .93, .93, .90, .81 olarak bulunmuştur. Öz bildirime dayalı olan ölçekte, kişilere ebeveynliğe dair çeşitli durumlar sunulmuş ve kendilerine ne sıklıkla bu durumu yaşadıkları sorularak, 7'li Likert ile ( $0=$ hiçbir zaman ve $6=$ hergün) değerlendirmeleri istenmiştir. 
Türkçe uyarlaması Arikan, Üstündağ-Budak, Akgün, Mikolajczak ve Roskam (2020) tarafından yapılmış olan ölçeğin, duygusal tükenmişlik, eskiden olunan ebeveyne zıtlık, bıkkınlık durumu ve duygusal mesafe alt ölçekleri için sirasıyla .84, .77, .77, .50 iç tutarlık katsayıları gösterdiği bulunmuştur. Duygusal mesafe alt boyutunun geçerlik konusunda sınırda gösterdiği iç tutarlık katsayısı göz önüne alınarak, bu çalışmada ilgili alt boyutların iç tutarlık kat sayılarına bakılmış ve sırasıyla $.92, .92, .85, .76$ olarak bulunmuştur. Ölçeklerin iç tutarlık katsayısı için kabul edilen eşik puanının .70'in üzerinde olduğu bilinmektedir (Tavakol ve Dennick, 2011). Bu kapsamda ilgili alt boyutlar çalışma kullanıma uygun psikometrik özelliklere sahiptir.

\section{Depresyon/Stres/Anksiyete Ölçeği (DASS-21)}

Lovibond ve Lovibond (1995) tarafindan bireylerin depresyon, anksiyete ve stres seviyelerini değerlendirmek amaciyla geliştirilen ölçeğin orjinali, 42 madde ve depresyon, anksiyete, stres olmak üzere 3 alt boyut içermektedir. Ölçek Henry ve Crawford (2005) tarafından alt boyutları aynı kalarak, 21 maddeye indirilerek kısaltılmıştır. Depresyon, anksiyete ve stres alt ölçekleri için sırasıyla .88, .82, .90 iç tutarlık katsayısına sahip olan ölçekte, öz bildirime dayalı olarak kişilere depresyon, anksiyete ve stres yaşantılarına ilişkin sorular yöneltilerek kişilerin bunları son bir haftadır ne sıklıkta yaşadıklarını 4'lü Likert skalasıyla (0= hiçbir zaman, 3=her zaman) değerlendirmeleri istenmektedir. Her alt boyut için alınan puan, ilgili alt ölçekteki semptomların şiddetiyle doğru orantılıdır.

Ölçeğin Türkçe uyarlaması Yılmaz, Boz ve Arslan (2017) tarafından yapılmış ve iç tutarlılık katsayısı depresyon, anksiyete ve stres alt ölçekleri için sırasıyla .82, .81, .76 olarak bulunmuştur. Daha önce yapılan araştırmalarda DASS-21 Depresyon alt ölçeğinin Beck Depresyon Envanteri gibi ölçeklerle korelasyon içinde olduğu ve tek başına kullanılabileceği görülmüştür (Daza, Novy, Stanley ve Averill, 2002; Vignola ve Tucci 2014). Buna uygun olarak, bu çalışmada da ölçeğin yalnızca "Depresyon" alt boyutu kullanılmıştır. 


\section{İşlem}

Nicel ve kesitsel araştırma deseni kapsamında yürütülen bu çalışmanın etik onayı FMV Işık Üniversitesi Etik Kurulu'ndan alınmıştır (Tarih: 24.12.2020 No:552). Çevrimiçi veri toplama aracı olan Google Forms üzerinden oluşturulan anket linki, gönüllü olarak katılmayı kabul eden katılımcıların doldurması için çeşitli platformlarda paylaşılmıştır. Ocak-Mart 2021 tarihleri arasında verileri toplanan çalışmanın anket bataryası, Bilgilendirilmiş Onam Formu'yla başlamış ve katılmayı kabul ettiğini işaretleyen katılımcılara sirasıyla, Sosyodemografik Bilgi ve Veri Formu, Yenilenmiş Çift Uyum Ölçeği (YÇUÖ), İş-Aile Çatışması Ölçeği (İAÇÖ), Ebeveyn Tükenmişlik Değerlendirmesi (ABT) ve Depresyon-Anksiyete-Stres Skalası Depresyon Alt Boyutu (DASS-21) sunulmuştur. Ana çalışmaya başlamadan önce 15 kişiyle pilot bir çalışma yapılmıştır. Anket veri seti dışında, ölçeklerin psikometrik özelliklerinin değerlendirildiği pilot çalışma sonunda, ana çalışmaya geçilmiş ve pilot çalışma verileri ana çalışmaya dâhil edilmemiştir. Katılımcıların anketi tamamlamasının ortalama olarak 10 dakika sürdügü raporlanmıştır.

\section{Veri Analizi}

Google Forms üzerinden çevrim içi olarak toplanan 761 kişilik veri seti, veri analizi için Windows SPSS v22 programına aktarılmıştır. Anketin içleme kriterlerini sağlamayan ve sağlasa dahi anketin tamamını cevaplamamış kişilerin veri setinden çıkarılmasıyla oluşan veri setinin, normallik dağılımı incelenmiştir. Normal dağılım için +3 ve -3 arasında yer alması beklenen basıklık ve çarpıklık değerleri kapsamında değerlendirilen verilerde (Byrne, 2016), 5 katılımcı Ebeveyn Tükenmişliği Değerlendirmesi (ABT) kapsamında uç değer olarak yer aldığı için veri setinden çıkarılmıştır. Bu kapsamda çalışmanın nihai örneklemini oluşturan 495 kadın katılımcıdan oluşan veri seti, veri analizine hazır hâle getirilmiştir.

\section{Araştırmanın Bulguları}

Bu bölümde öncelikle araştırmada kullanılan ölçek ve alt ölçeklerin psikometrik ve tanımlayıcı bulgularına, daha sonra korelasyon 
analizleri ve araştırmada kullanılan İş-Aile Çatışması Ölçeği puanlarının pandemi sürecinde evden tam zamanlı ya da evden yarı zamanlı çalışma durumuyla çocuk yaşına göre farklılaşıp farklılaşmadığını değerlendirmek için yapılan bağımsız örneklem t-test ile tek yönlü varyans analizi (ANOVA) bulgularına ve son olarak hiyerarşik regresyon analizi bulgularına yer verilmiştir. Çalışmada kullanılan tüm ölçeklerin psikometrik ve tanımlayıcı bulguları Tablo 2'de, korelasyon bulguları ise Tablo 3’te sunulmuştur.

Tablo 2. Çalışmada Kullanılan Ölçeklerin Betimsel İstatistik ve İç Tutarlılık Değerleri

\begin{tabular}{lccccc}
\hline Ölçekler & N & $\begin{array}{c}\text { Orta- } \\
\text { lama }\end{array}$ & $\begin{array}{c}\text { Standart } \\
\text { Sapma }\end{array}$ & $\begin{array}{c}\text { Min- } \\
\text { Maks }\end{array}$ & $\begin{array}{c}\text { Cron- } \\
\text { bach Alfa }\end{array}$ \\
\hline DASS-21 & 495 & 6.16 & 4.05 & $0-21$ & .87 \\
YÇUÖ - Toplam & 495 & 51.21 & 9.29 & $18-70$ & .90 \\
YÇUÖ - Uzlaşma & 495 & 9.71 & 2.11 & $3-15$ & .72 \\
YÇUÖ - Doyum & 495 & 18.49 & 3.86 & $6-25$ & .77 \\
YÇUÖ - Görüş birliği & 495 & 23.01 & 4.64 & $6-30$ & .83 \\
İÇÖ - İş-aile Çatışması & 495 & 15.16 & 5.24 & $5-25$ & .91 \\
İAÇÖ - Aile-iş Çatışması & 495 & 11.90 & 4.58 & $5-25$ & .85 \\
ABT - Toplam & 495 & 25.48 & 25.86 & $0-125$ & .96 \\
ABT - Duygusal Tüken- & 495 & 11.82 & 16.93 & $0-49$ & .92 \\
mişlik & 495 & 6.46 & 7.82 & $0-36$ & .92 \\
ABT - Eskiye Zıtlık & 495 & 4.16 & 5.38 & $0-30$ & .85 \\
ABT - Bıkkınlık & 495 & 3.06 & 5.53 & $0-17$ & .76 \\
ABT - Duygusal Mesafe & & & & & \\
\hline
\end{tabular}

Not: DASS-21: Depresyon/Anksiyete/Stres Ölçeği, YÇUÖ: Yenilenmiş Çift Uyum Ölçeği, İAÇÖ: İş-Aile Çatışması Ölçeği, ABT: Ebeveyn Tükenmişliği Ölçeği 


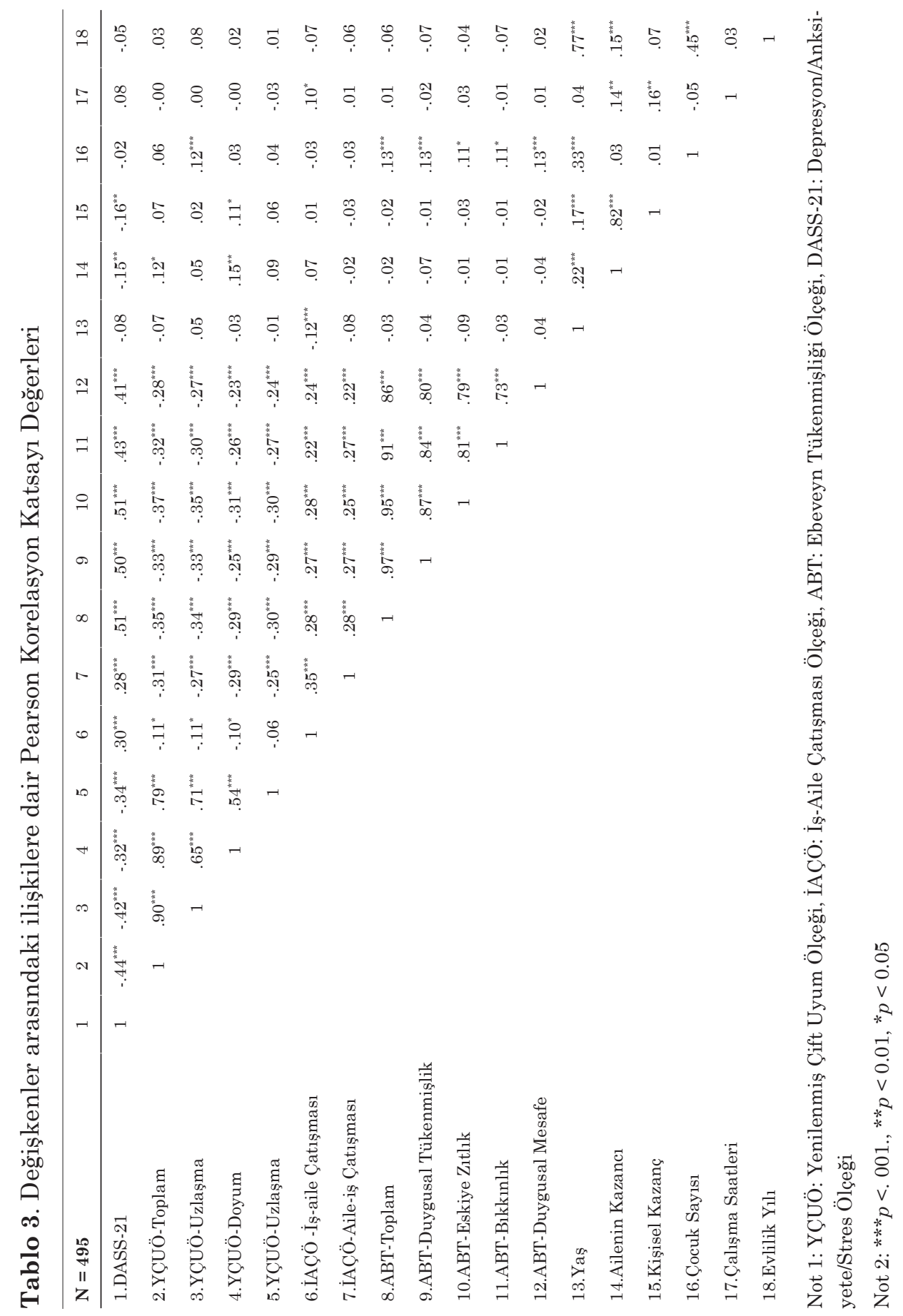


Korelasyon analizi sonuçlarına göre, depresyon puanlarının, evlilik uyumuyla negatif yönde, orta kuvvette ve anlamlı bir ilişkisi olduğu $(r=-.44, p=.000)$; İş-Aile Çatışması Ölçeği'yle değerlendirilen iş-aile çatışmasının, alt boyutları "iş-aile çatışması" ( $r=.30, p=$ $.000)$ ve "aile-iş çatışması" ( $r=.28, p=.000)$ ile pozitif yönde, zayıf ve anlamlı bir ilişkisi olduğu ve son olarak ebeveyn tükenmişliğiyle $(r=$ $.51, p=.000$ ) pozitif yönde ve orta kuvvette ilişkisi olduğu bulunmuştur. İş-Aile Çatışması Ölçeği'nin iş-aile çatışması $(r=.28, p=.000)$ ve aile-iş çatışması $(r=.28, p=.000)$ alt ölçeklerinin ise ebeveyn tükenmişliğiyle pozitif yönde ve zayıf kuvvette anlamlı birer ilişkisi olduğu görülmektedir. Ayrıca, çift uyumunun iş-aile çatışması ( $r=$ $-.11, p=.017)$ ve aile-iş çatışmasıyla $(r=. .31, p=.000)$ negatif yönde ve zayıf kuvvette anlamlı ilişkisi bulunmuştur. Son olarak, ebeveyn tükenmişliği ve çift uyumu arasında negatif yönde ve orta kuvvette bir ilişki olduğu görülmüştür $(r=-.33, p=.000)$. Sosyodemografik özellikler ve temel değişkenlerin ilişkisine bakıldığında ise yaş kriterinin iş-aile çatışması ile $(r=-.12, p=.000)$ negatif yönde ve zayıf bir ilişkisi olduğu görülmüştür. Ailenin toplam kazancının depresyonla negatif yönde ve zayıf olacak şekilde ilişkisi $(r=-.15, p=.002)$ ve çift uyumuyla pozitif yönde ve zayıf olacak şekilde ilişkisi ( $r=.12, p$ $=.013)$ saptanmıştır. Kişinin sahip olduğu çocuk sayısının değişkenin Yenilenmiş Çift Uyum Ölçeği'nin Uzlaşma Alt Ölçeği'yle pozitif yönde ve zayıf ( $r=.12, p=.009)$, Ebeveyn Tükenmişlik Ölçeği’nin (ABT) toplam puanıla pozitif yönde ve zayıf $(r=.13, p=.005)$ ilişkisi olduğu görülmüştür.

Korelasyon analizinin ardından, iş-aile çatışması puanlarının tamamen evden çalışma durumu ve çocuk yaşına göre istatistiksel olarak farklılaşıp farklılaşmadığını değerlendirmek amacıyla bağımsız örneklemler t-testi (Independent Sample T-test) ve tek yönlü varyans analizi yapılmıştır. İş-aile çatışması puanlarının tamamen evden çalışan kadınlarla hem ofisten hem evden çalışan katılımcılar arasındaki farkının incelenmesi için yapılan bağımsız örneklem t-test analizinde iş-aile çatışması alt boyutunda her iki grup arasinda anlamlı bir fark olduğu bulunmuştur $(t(493)=2.26, p<0.05)$. Tamamen evden çalışan katılımcıların $(O r t=15.6, S S=5.28)$, hem 
ofisten hem evden çalışan katılımcılara (Ort $=14.5, S S=5.13)$ kıyasla, iş-aile çatışması alt boyutundan istatistiksel olarak daha yüksek puan aldıkları bulunmuştur. İş-Aile Çatışması Ölçeği alt boyut puanlarının, çocukların yaş grubuna göre farklılık gösterip göstermediğini incelemek için yapılan tek yönlü varyans analizi (ANOVA) sonuçlarına göre, çocuk yaşlarına göre annelerin deneyimlediği iş-aile çatışması puanlarında istatistiksel olarak anlamlı bir fark olduğu bulunmuştur, $F(3,491)=3.12, p<.005$. Yapılan Bonferonni post-hoc analizinde, iş-aile çatışması kategorisinde grupların ortalaması 0-2 yaş grubu için $16.02(S S=4.82)$, 3-5 yaş grubu için $15.25(S S=5.37)$, 6-12 yaş grubu için $14.23(S S=5.30)$ ve son olarak 13-18 yaş grubu için 15.83 ( $S S=5.22$ ) olarak bulunmuş; 0-2 yaş grubunda çocuğu olan anneler, 6-12 yaş çocuğu olan annelere kıyasla iş-aile çatışması kategorisinde istatistiksel olarak anlamlı düzeyde daha yüksek puanlar almıştır.

Çalışmanın ana amacı olan, iş-aile çatışması, evlilik uyumu ve ebeveynlik tükenmişliğinin depresyon üzerindeki yordayıcı rolünün test edilmesi için Hiyerarşik Çoklu Regresyon Analizi yapılmadan önce, depresyonu yordayan sosyodemografik değişkenlerin belirlenmesi için Basit Doğrusal Regresyon Analizi yapılmıştır. Analiz sonuçlarına göre sosyodemografik değişkenlerden yalnızca aylık kazanç depresyonu yordarken $(\beta=.18, t(423)=-3.51, p<.001)$, çalışma şekli, çalışma saati, çocuk sayısı, çocuk yaşı, katılımcının yaşı ve evlilik yılı değişkenleri yordamamıştır. Bu sonuçlara göre, depresyon üzerinde yordayıcı etkisi olan aylık kazanç değişkenin etkisi kontrol edilmek üzere Hiyerarşik Çoklu Regresyon Analizi’ne dâhil edilmiştir.

Hiyerarşik Çoklu Regresyon Analizi gerçekleştirilmesinin amacı depresyon belirtilerini yordayabilecek değişkenleri saptamaktır. Ölçeklerin hangi boyutlarının depresyonu yordadığını belirlemek için ölçekler alt boyutlarıyla analize dâhil edilmiştir. Değişkenler dört aşamalı regresyon analizine sokulmuştur. Değişkenler, ilk basamakta sosyodemografik değişkenin, sonrasında ise korelasyon katsayısına göre ilişki gücü göz önüne alınarak önem sırasına göre 
modele dâhil edilmiştir ve her değişkenin girdiği surada eşitliğe olan katkısı değerlendirilmiştir. İlk aşamada bireyin sosydemografik değişkenlerinden depresyon için yordayıcı bulunan aylık kazanç, ikinci aşamada iş-aile çatışması, üçüncü aşamada evlilik uyumu ve son olarak dördüncü aşamada ise ebeveyn tükenmişliği ölçekleri alt boyutlarıyla analize sokulmuştur. Her dört aşamada da analize sokulan her bir değişkenin etkisini görmek adına "Zorunlu Giriş (enter)" yöntemi kullanılmıştır. Hiyerarşik Çoklu Regresyon analizi sonuçları, Tablo 4'te gösterilmiştir.

Tablo 4. Hiyerarşik Çoklu Regresyon Tablosu

$\begin{array}{lllllll}\text { Yordayicilar } & B & \beta & t & R^{2} & R^{2} \text { Change }\end{array}$

\begin{tabular}{|c|c|c|c|c|c|}
\hline $\begin{array}{l}\text { I } \\
\text { Aylık Kazanç }{ }^{* * *}\end{array}$ & .00 & 18 & -3.51 & .03 & .025 \\
\hline II & & & & .16 & .131 \\
\hline 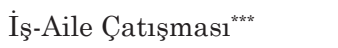 & .21 & .26 & 5.48 & & \\
\hline Aile-İş Çatışması ${ }^{* * *}$ & .16 & .18 & 3.82 & & \\
\hline III & & & & .29 & .137 \\
\hline Doyum $^{* * *}$ & -.22 & -.21 & -3.20 & & \\
\hline Görüş Birliğï** & -.13 & -.16 & -2.74 & & \\
\hline Uzlaşma & -.15 & -.08 & -1.35 & & \\
\hline IV & & & & .41 & .117 \\
\hline Duygusal Tükenmişlik $^{* * *}$ & .11 & .31 & 3.40 & & \\
\hline Eskiye Zitlık & .09 & .17 & 2.02 & & \\
\hline Bıkkınlık & -.06 & -.08 & -1.12 & & \\
\hline Duygusal Mesafe & -.02 & -.01 & -.21 & & \\
\hline
\end{tabular}

Not: $*$ İstatistiksel olarak anlamlı bulunan değişkenler, ${ }^{* * *} p<.001 .,{ }^{* *} p<0.01,{ }^{*} p<0.05$ 
İlk aşamada analize sokulan, sosyodemografik değişkenlerden aylık kazancın dâhil olduğu model istatistiksel olarak anlamlıdır [ $F$ $(1,429)=11.12, p<.001)]$ ve varyansın \%3’ünü açıklamıştır. Modeldeki değişken olan aylık kazanç depresyon belirtilerini istatistiksel olarak anlamlı ve negatif yönde yordamıştır $[(\beta=-.18, t(429)=-3.51$, $p<.001)]$.

İkinci aşamada analize sokulan, iş-aile çatışması ve aile-iş çatışması değişkenlerini içeren ikinci model istatistiksel olarak anlamlı bulunmuştur $[(F(3,427)=26.46, p<.001)]$ ve varyansın \%13’ünü açıklamıştır. Bu modelle birlikte açıklanan toplam varyans \%16 olmuştur. Bu modeldeki iki değişken olan, "İş-Aile Çatışması" alt boyutu $[(\beta=.26, t(427)=5.48, p<.001)]$ ve "Aile-İş Çatışması" alt boyutu $[(\beta=.18, t(427)=3.82, p<.001)]$ depresyon belirtilerini istatistiksel olarak anlamlı ve pozitif yönde yordamıştır.

Üçüncü aşamada analize dâhil edilen ve evlilik uyumu alt boyutları olan doyum, görüş birliği ve uzlaşma değişkenlerini içeren üçüncü model istatistiksel olarak anlamlı bulunmuş $[(F(6,424)=$ $29.46, p<.001)]$ ve varyansın \%14'ünü açıklamıştır. Açıklanan toplam varyans \%29'a çı kmıştır. Bu modeldeki üç değişkenden "Doyum" $[(\beta=-.21, t(424)=-3.20, p<.001)]$ ve "Görüş Birliği” [ $(\beta=-.16, t(424)$ $=-2.74, p<.01)]$ depresyon belirtilerini negatif yönde istatistiksel olarak anlamlı olarak yordarken, "Uzlaşma" değişkeni ise yordamamaktadır.

Dördüncü aşamada analize sokulan, duygusal tükenmişlik, eskiye zıtlık, bıkkınlık ve duygusal mesafe değişkenlerini barındıran dördüncü model istatistiksel olarak $[(F(10,420)=29.38, p<.001]$ bulunmuş ve varyansın \%12'sini açıklamıştır. Böylece açıklanan toplam varyans \%41'e çıkmıştır. Bu modeldeki dört değişkenden "Duygusal Tükenmişlik" $[(\beta=.31, t(420)=3.40, p<.001)]$ ve "Eskiye Zitlı" $[(\beta=.17, t(420)=2.02, p<.05)]$ depresyon belirtilerini istatistiksel olarak anlamlı ve pozitif yönde yordarken, "Bıkkınlık" ve "Duygusal Mesafe" ise yordamamaktadır. 


\section{Tartışma}

Bu çalışmada, ülkemizde pandemi döneminde evden çalışma deneyimi yaşayan, evli ve 18 yaş altı çocuğu olan kadınların depresyon düzeyini yordamada iş-aile çatışması, evlilik uyumu ve ebeveynlik tükenmişliğinin rolü araştırılmıştır. Türkiye'nin tüm bölgelerinden 24-55 yaş arası 495 kadının yer aldığı bu çalışmada, katılımcıların yarısından fazlası pandemi nedeniyle evden çalışırken, kalan bölümünün bazı zamanlar evden bazı zamanlar ise ofisten çalıştığı görülmüştür. Bununla beraber, annelerin büyük çoğunluğu 6-12 yaş çocuk sahibi iken, bunu sırasıyla 3-5 yaş arası, 0-2 yaş arası ve 13-18 yaş arası çocuk sahibi anneler izlemektedir. Bu kapsamda temel analizler öncesinde, evden çalışma durumunun ve çocuk yaşının katılımcıların iş-aile çatışması ölçeği alt boyutları puanlarında bir farklılık yaratıp yaratmadığı değerlendirilmiştir. Evden çalışan evli annelerin, iş-aile çatışmasının alt boyutu olan 'iş-aile çatışması' için aldıkları puanın, bazen evden bazen ofisten çalışan evli annelere göre anlamlı derecede daha yüksek olduğu bulunmuştur. Bu bulgu, pandemi öncesi yürütülen çalışma sonuçlarıyla benzerlik göstermektedir. Sullivan (2000), evden çalışmanın, kişinin ailesi ve işi arasındaki sınırların kaybolmasına sebep olduğu ve her iki alanda da görevlerin yapılmasını zorlaştırdığını belirtmektedir. İş-aile çatışmasını değerlendiren ölçeğin iki farklı boyutu olduğu ve yalnızca 'iş-aile çatışması' alt boyutunun (işin aileyi bölmesi), anlamlı çıtı̆̆ğı göz önünde bulundurulduğunda, işteki ağır sorumluluklar ve meslekî görevlerin fazlalığının bu çatışmaya neden olabileceği düşünülmektedir (Mesmer-Magnus ve Viswesvaran, 2005). Pandemi sürecinde verisi toplanan bu çalışmada, 'iş-aile çatışması' durumunun düzenli olarak evden çalışan evli annelerde anlamlı olarak daha yüksek olması, pandeminin kadınlar üzerine getirdiği ağır yüklerin bir göstergesi niteliğindedir. Pandemide yapılan çalışmalar özellikle çocuğu olan ve çalışan kadınların zorlandıklarına işaret ederken (Bayazıt ve Türetgen, 2021), çalışma bulgularımızı da destekler niteliktedir. 
Düzenli olarak evden çalışma durumuna ek olarak, bu çalışma kapsamında, çalışan evli annelerde, çocuk yaşının da iş-aile çatışması üzerinde önemli bir rolü olduğu bulunmuştur. Yapılan ileri analizlerde bu farkın 0-2 yaş arası çocuğu olan annelerden kaynaklandığı, bu yaş grubundan çocuğu olan annelerin deneyimlediği iş-aile çatışmasının 6-12 yaş arası çocuğu olan annelere göre daha fazla olduğu görülmektedir. Küçük yaştaki çocukların, özellikle de çalışan anneler için daha fazla iş-aile çatışmasıyla ilişkilendirilmesi bulgusu literatürle uyumlu görünmektedir (Ahmad, 2008; Darcy ve McCarthy, 2007). 0-2 yaştaki çocukların bağımsızlıklarının çok düşük olması ve anneden ayrılmakta güçlük çekmeleri gibi bir durum söz konusuyken; 6-12 yaş arası çocuklar artık "orta ve ileri çocukluk" döneminde olup okul çağına erişmişlerdir (Santrock, 2015). Yaş grupları arasındaki bu ayrımın çocukların bağımsızlık ve dünyayı aileden uzaklaşarak keşfetme seviyelerindeki farktan kaynaklandığı söylenebilir.

Birinci basamakta modele eklenen aylık kazancın depresyonu negatif yönde anlamlı olarak yordadığı bulunmuştur. Bu konuda alanyazında yürütülen çalışmalar incelendiğinde, 17 yıl boyunca sürdürülmüş ve kişinin aylık kazancının depresyon, anksiyete ve genel fonksiyonları üzerindeki yordanabilirliğini ölçen bir araştırmaya göre, kişinin aylık kazancı hem mevcut hem de gelecekteki depresyonu yordamaktadır (Wood, Boyce, Moore ve Brown, 2012). Bu bulgular kişinin maddi durumu azaldıkça depresyon seviyesinin artacağını söyleyen çalışmalarla uyum göstermektedir (Akhtar-Danesh ve Landeen, 2007; Islam \& Adnan, 2017; Segre, O’Hara, Arndt ve Stuart, 2007; ve Sareen, Afifi, McMillan \& Asmundson, 2011). Genel popülasyon dışında, ebeveyn olan kadınların depresyon belirtileri ve maddi durumları arasındaki ilişki incelendiğinde maddi durumu düşük olan annelerin maddi durumu yüksek olan annelere göre daha fazla depresif semptomlar gösterdiği bilinmektedir (RichEdwards vd., 2006). Annelerde depresif semptomlar ve maddi durum arasındaki ilişkiyi oluşturan faktörler incelendiğinde, aylık geliri düşük olan yeni doğum yapmış annelerle yapılan nitel bir çalışma; bu ilişkilerin anneliğe dair duyulan ikili duygular, çocuk bakımının 
annenin üzerine aşırı derecede yüklenmesi, birçok şeyi aynı anda yapmaya çalışmak ve tek başına annelik yapmak gibi gündelik hayatta yaşanan sorunlarla alakalı olduğunu söylemiştir (Abrams ve Curran, 2009). Yapılan bu nitel çalışmanın sonuçları, ebeveyn olan kadınlarda depresyonu açıklamak için maddi durumla beraber, mevcut çalışmada sözü geçirilen "annelik görevleri”, "ebeveynliğe dair duygular", "rol karmaşası" gibi kavramları da kapsayarak mevcut çalışmayı birçok yönden desteklemiştir.

İkinci basamakta eklenen, iş-aile çatışmasının hem 'iş-aile çatışması' hem de 'aile-iş çatışması' alt boyutunun depresyonu pozitif yönde anlamlı olarak yordadığı bulunmuştur. İş-aile çatışmasının depresyonla ilişkisi alanyazında sıklıkla araştırılmaktadır ve yordayıcılık ilişkisi pek çok bulguyla desteklenmektedir (Du Prel ve Peter, 2015; Obidoa vd., 2011). İş-aile çatışması deneyiminin kişinin kendi benlik saygısını zedeleyebileceğine ve bu nedenle de depresyona neden olduğuna yönelik görüşler bulunmaktadır (Frone, Russell ve Cooper, 1992). Bunun dışında, evden çalışma durumunun birbirinden ayrı alanlar arasındaki sınırları zedeleyeceğinden ötürü iş-aile çatışmasına yol açacağı söylenmektedir (Sullivan, 2000). Pandemi süreci göz önünde bulundurulduğunda ise Türkiye'de COVID-19 pandemisinin evden çalışmak zorunda kalan kişiler üzerinde etkisini araştıran bir çalışmaya göre, evden çalışılan gün sayısı arttıkça kişinin deneyimlediği iş-aile çatışmasının da arttığ̣ ve bu durumdan en çok etkilenenlerden birinin küçük çocuğu olan anneler olduğu görülmüştür (Bayazıt ve Türetgen, 2021). Bu çalışmadaki pandemi sürecinde evden çalışan ve evli annelerde görülen bulguların pandemi öncesi ve sonrasında yapılan çalışmalarla benzer sonuçlara sahip olduğu söylenebilir.

Üçüncü basamakta eklenen evlilik uyumu değişkeninde, "Doyum" ve "Görüş Birliği” alt boyutunun, evli kadın ebeveynlerde depresyonu negatif yönde anlamlı olarak yordarken, "Uzlaşma" değişkeninin yordamadığı bulunmuştur. Evlilik uyumunun depresyonu yordadığı pek çok çalışma tarafından desteklenmektedir (Henry, Berg, Smith ve Florsheim, 2007; Proulx, Helms ve Buehler, 2007; 
Whisman, 2001). Evlilik uyumu değişkenlerinden doyum ve görüş birliği alt boyutunun depresyonu yordaması bulgusu, alt boyutların her birinin hangi bileşenlerden oluştuğu göz önüne alınarak değerlendirilmelidir. Ölçeğin faktör analizi yapılırken her alt ölçeğin kendine ait kategorileri olduğu görülmüştür. Yapılan analiz sonuçlarında "Görüş Birliği” ve "Doyum" alt ölçeklerinin kendilerini oluşturan kategorilerle olan korelasyonunun, "Uzlaşma” alt ölçeğiyle kıyaslandığıında daha fazla olduğu görülmüştür (Busby vd., 1995). Bir başka deyişle, "Görüş Birliğì" ve "Doyum” alt ölçeklerinin evlilik uyumunu temsil edebilirliğinin "Uzlaşma" alt ölçeğine göre daha fazla olabileceği söylenebilir ve bu durum mevcut çalışmadaki bulgularla uyumludur. Ölçeğin alt boyutlarıyla ilişkilendirilen faktörlerin neler olduğu da önem taşımaktadır. "Uzlaşma” alt ölçeğinin karar alma, değerler ve duygular; "görüş birliği” alt ölçeğinin eş ile yapılan aktiviteler ve fikir alışverişi; “doyum” alt ölçeğinin ilişkideki denge ve çatışma durumuyla ilişkili olduğu görülmektedir (Busby vd., 1995). Alanyazında, "Doyum" alt boyutuyla ilişkilendirilmiş olan çatışma durumuyla depresyon arasında anlamlı bir ilişkiden söz edilmektedir (Mackinnon vd, 2012; Westdahl vd., 2007). Kişinin eşiyle olan evlilik ilişkisinde doyumsuzluk hissetmesi, evliliğinde göreceği destek, ilgi ve sıcaklık gibi olumlu kaynaklarını azaltarak depresyona zemin hazırladığı bilinmektedir (Dehle, Larsen ve Landers, 2001). Bunun dışında, depresyonu anlamlı şekilde yordayan diğer bir alt ölçeğin "Görüş Birliğ̣i” olduğu ve bu alt ölçeğin ilişkili faktörlerden birinin beraber geçirilen zaman/yapılan aktiviteler olduğu söylenmiştir. Alanyazında eşlerin beraber geçirdiği kaliteli zamanın evlilik uyumunu etkileyebileceği belirtilmekte (Johnson ve Anderson, 2012; Russell-Chapin, Chapin ve Sattler, 2001) ve mevcut çalışmada edinilen bulgular alanyazınla uyumlu görünmektedir. Ancak bu noktada partnerlerin yalnızca beraber ne kadar süre geçirdikleri değil, geçirilen vaktin kalitesi ve bu deneyimin kişilerin beklentilerine ne derece uygun olup olmadığı da incelenmelidir. Örneğin, bu konuda yapılan bir çalışma evli çiftlerin beraber geçirdikleri vaktin artmasının erkek için evlilik uyumunu düşürdüğünü ve hatta boşanmayla ilişkili olduğunu bulmuş ve erkeklerin vakit geçirme beklentilerinin 
eşlerinden daha farklı olduğu için böyle bir sonuca yol açabileceğini söylemiştir (Gager ve Sanchez, 2003). Bu noktada geçirilen vaktin nasıl bir bağlamda gerçekleştiği özellikle de pandemi gibi bir dönemde büyük bir önem taşımaktadır. Çin'de yapılan bir araştırma COVID-19 pandemi süresince çiftlerin beraber geçirdiği uzun vaktin artmasının aile içi çatışmaya yol açtığını ve bunun da boşanmayla sonuçlanabildiğini söylemiştir (Zhang, 2020). Yine aynı araştırma iki aylık karantina dönemi sonrasında boşanma oranlarının arttığını belirtmiştir. Türkiye'de bu konuda yapılan nitel bir çalışma, pandemi kaynaklı yaşanan stresin evlilikteki etkileşim üzerinde olumsuz etkileri olduğu, uzun süre aynı evde kalınması sonucunda çatışmaların arttığı ve bunun da evlilikteki doyumu azalttığ muştur (Kaya ve Akın, 2021). Bu noktada, mevcut çalışmanın sonuçları alanyazındaki araştırmalarla uyumlu görünmekte ve pandemi süresince veri toplandığı göz önüne alındığında, evlilik uyumunun deneyimlenme şekli dikkat çekmektedir.

Dördüncü aşamada modele eklenen, ebeveyn tükenmişliğinin, evden çalışan evli ve çocuğu olan kadınlarda depresyonu yormadaki rolü incelendiğinde "Duygusal Tükenmişlik" ve "Eskiye Zıtlık" boyutunun depresyon belirtilerini pozitif yönde anlamlı olarak yordadığı bulunmuştur. İlgili bulgunun değerlendirilmesi için yapılan çalışmaların sıklığı ve sonuçları göz önüne alındığında, duygusal tükenmişlik kavramı ve depresyon ilişkisinin sıklıkla incelendiği ve çalışmamızın benzer bulgularla desteklendiği görülmüştür (Örn. Jeon, Buettner ve Grant, 2018; Santa Maria vd., 2018). Bunun d1şında, duygusal tükenmişlik kavramının, ölçeğin diğer alt boyutlarına göre uyku sorunları ve hayattan alınan doyumla daha yüksek ilişkili olduğu bilinmektedir (Aunola, Sorkkila ve Tolvanen, 2020; Stănculescu, Roskam, Mikolajczak, Muntean ve Gurza, 2020). Depresyonun uyku sorunlarıyla (Sariarslan, Gulhan, Unalan, Basturk ve Delibas, 2015) ve hayattan alınan doyumla (Serin, Serin ve Özbaş, 2010) negatif yönde ilişkili olduğu bilinmektedir ve bu nedenle de duygusal tükenmişliğin depresyonla ilişkili olması beklenen bir durumdur. "Eskiye Zıtlık" kavramının ise ölçeğin geliştiricileri tarafından tükenmişlik hâline özgü bir durum olduğunu ve eğer kişi 
eski ebeveynlik hâline karşı zıtlık içinde değilse kişinin tükenmişlik içinde olmayabileceğini öne sürmüştür (Roskam, Brianda ve Mikolajczak, 2018). Bunun dışında, ölçeğin diğer faktörlerle korelasyonunu gösteren bir çalışmaya göre, eskiye zıtlık alt ölçeğinin duygusal tükenmişlik sonrasında depresyonla ilişkisi en yüksek ve çift uyumuyla en fazla ilişkili olan alt ölçek olduğu bulunmuştur (Szczygieł, Sekulowicz, Kwiatkowski, Roskam ve Mikolajczak, 2020). Yine aynı çalışmanın sonuçlarına göre, eskiye zıtlık alt ölçeğinin depresyonla sıklıkla ilişkilendirilmiş nörotisizm kavramıyla diğer ölçeklere göre daha güçlü ilişkisi olduğu görülmüştür (Kendler, Kuhn ve Prescott, 2004). Sonuç olarak, alanyazında yer alan araştırmalar mevcut çalışmanın sonuçlarıyla uyumlu görünmektedir. Depresyon ile ebeveyn tükenmişliği kavramı incelendiğinde, ebeveynliğin mükemmel olarak hayal edilmesi ve özellikle de annelerin üzerinde "iyi anne" baskısının oluşmasının zaman içinde stresini kontrol etmesi için kişiyi araçsız bırakacağı, ebeveyn tükenmişliğine sebep olacağı, kişinin kendisini bomboş hissetmesine yol açacağı (Hubert ve Aujoulat, 2018), bunun da depresyon için zemin hazırlayacağı öngörülmektedir. Öte yandan, bulgular alanyazındaki çalışmalarla paralellik gösterse de bu çalışmanın örneklemini 18 yaş altı çocuklu evden çalışan evli kadınlar oluşturmaktadır. Pandemi sürecinde, önlemlerin sıkı olarak uygulandığı bir sürede veri toplandığı göz önüne alındığında, 18 yaş altı çocukların evde olmaları ve evde olmalarının getirdiği sorumlulukla birlikte, azalan destek kaynakları nedeniyle katılımcıların duygusal olarak tükenmişliğinin ve eskiye zıtlı̆̆ının yüksek olabileceği, bunun depresyon için önemli bir risk faktörü olarak yordayıcı rolü olduğu göz önüne alınmalıdır. Bu kapsamda, temel eğitim sürecinde okulların açık olarak eğitime devam ediyor olması, sadece çocukların gelişimi açısından değil, aynı zamanda çalışan annelerde tükenmişlik düzeyi açısından da koruyucu olacaktır.

Bu çalışmanın bazı kısıtlılıkları vardır. Bunlardan ilki öz bildirime dayalı ölçüm araçlarının kullanılmış olmasıdır. Yanıtların katılımcıların beyanıyla kısıtlı olmasına ek olarak, sosyal beğenirlik etkisi içermesi olasıdır. Çalışmanın bir diğer kısıtlılı̆̆ı, çalışmaya katılan örneklem özelliğiyle ilişkili genellenebilirlik durumudur. 
Çalışmanın verisi online olarak toplanmış olup internet erişimli katılımcılardan oluştuğu göz önüne alınmalıdır. Ek olarak, katılımcılarının çoğunun üniversite ve üzeri eğitim seviyesine sahip olması bulgunun diğer eğitim düzeylerine sahip ve eğitim düzeyiyle yakından ilişkili olabilecek çalışma durumlarına genellenebilirliğini kısıtlamaktadır. Son olarak, bu çalışmada, içinde bulunduğumuz pandemi sürecinde evden çalışan kişiler seçilmiş olsa da pandemi öncesi çalışma koşulları değerlendirilmemiştir; pandemi öncesinde de evden çalışan ve pandemi dolayısıyla evden çalışmaya başlayan kişiler arasında bir ayrım yapılmamıştır. Bu kapsamda, evden çalışmak zorunda kalan ve daha öncesinde kendi istekleri üzerine evden çalışan kişiler arasındaki farkların incelenme şansı olmamıştır.

İleride yapılacak çalışmaların hem anneleri hem babaları dâhil ederek, araştırılan kavramları değerlendirmesi önerilmektedir. Ek olarak, boylamsal çalışmaların yapılması hem pandemi sürecinde bu değişkenlerin değişiminin incelenmesi hem de pandemi bittikten sonra değişen çalışma şekli kapsamında değerlendirilmesinin alanyazına büyük katkı sunacağı düşünülmektedir.

\section{Sonuç}

Depresyonun kadınlarda yaygın olduğu göz önüne alındığında, çalışma kapsamında elde edilen bulguların depresyonla müdahale programlarında, içinde bulunduğumuz pandemide yol gösterici olacağı düşünülmektedir. İş-aile çatışmasının depresyon üzerindeki yordayıcı rolü düşünüldüğünde, organizasyonel açıdan kurumların iş-aile çatışmasını azaltacak politikalar uygulamasının gerekliliği görülmektedir. Özellikle çocuğu olan kadın çalışanların, evden çalışma sürecinde ebeveynlik yükleri de göz önüne alınarak, iş yükü ve çalışma saatleri konusunda esneklik sunmaları ve iş yeri psikoloğu bulundurmaları hem çalışanların psikolojik sağlığı hem de organizasyonun uzun vadeli yararı açısından gerekli görülmektedir. İş-aile çatışmasına ek olarak, ebeveynlik tükenmişliği göz önüne alındığında, özellikle pandemi döneminde 0-2 yaş arasında çocuğu olan, evli ve evden çalışan anneler için sosyal destek mekanizmalarının 
geliştirilmesinin, iş ve aile çatışmasının önüne geçerek depresyon için önleyici olacağı düşünülmektedir. Bunun dışında, çalışma bulguları evli, 18 yaş altı çocuğu olan ve evden çalışan kadınlarda evlilik uyumunun önemine işaret etmektedir. İçinde bulunduğumuz süreçte, evlilik çatışması yaşayan bireylerin evliliklerine yönelik müdahale programlarının sunulması, çift ve aile terapisi almaya cesaretlendirilmesi ve evlilik uyumunun arttırılması önceliklendirilmelidir. Aylık kazancın depresyon üzerindeki etkisi göz önünde bulundurulduğunda, bahsi geçen müdahale programlarının ücretsiz ya da uygun ücretli olması önem taşımaktadır. Buna istinaden, klinik psikoloji yüksek lisans öğrencilerinin staj ya da tez programları kapsamında grup müdahaleleri yapmaları hem akademik anlamda hem halk sağlığı adına yararlı olacaktır.

Bu çalışma kapsamında elde edilen bulguların, COVID-19 pandemi döneminde evden çalışan evli ve 18 yaş altı çocuklu kadınların depresyon düzeylerine etki eden faktörleri açı̆̆a koyması yanında ilgili müdahale programlarının geliştirilmesi için yol gösterici olacağı düşünülmektedir.

\section{Kaynakça}

Abrams, L. ve Curran, L. (2009). "And You're Telling Me Not to Stress?” a Grounded Theory Study of Postpartum Depression Symptoms among Low-Income Mothers. Psychology Of Women Quarterly, 33(3), 351-362. https://doi.org/10.1177/036168430903300309

Ahmad, A. (2008). Job, Family and Individual Factors as Predictors of WorkFamily Conflict, The Journal of Human Resource and Adult Learning, 4 (1).

Akçınar, B. (2020). Ebeveynlik Davranışları ve Çocukların Sosyal-Davranışsal Gelişiminde İş-Aile Çatışmasının Rolü (Proje No. 118K170). TÜBİTAK.

Akhtar-Danesh, N. ve Landeen, J. (2007). Relation between depression and sociodemographic factors. International Journal of Mental Health Systems,1(1). https://doi.org/10.1186/1752-4458-1-4

Allen, T. D., Herst, D. E., Bruck, C. S. ve Sutton, M. (2000). Consequences associated with work-to-family conflict: A review and agenda for future 
research. Journal of Occupational Health Psychology, 5(2), 278-308. https://doi.org/10.1037/1076-8998.5.2.278

Almeida, M., Shrestha, A., Stojanac, D. ve Miller, L. (2020). The impact of the COVID-19 pandemic on women's mental health. Archives Of Women's Mental Health, 23(6), 741-748. https://doi: 10.1007/s00737-020-01092-2

Anderson, S. E., Coffey, B. S. ve Byerly, R. T. (2002). Formal organizational initiatives and informal workplace practices: Links to work-family conflict and job-related outcomes. Journal of Management, 28(6), 787 810. https://doi.org/10.1177/014920630202800605

APA. (2013). DSM-5 tanı ölçütleri başvuru el kitabı. Ankara: Hekimler Yayın Birliği Yayıncılık.

Arikan, G., Üstündağ-Budak, A. M., Akgün, E., Mikolajczak, M. ve Roskam, I. (2020). Validation of the Turkish version of the Parental Burnout Assessment (ABT). New Directions for Child and Adolescent Development, 2020(174), 15-32. https://doi.org/10.1002/cad.20375

Arntz, M., Ben Yahmed, S. ve Berlingieri, F. (2020). Working from Home and COVID-19: The Chances and Risks for Gender Gaps. Inter Economics, 55(6), 381-386. https://doi.org/10.1007/s10272-020-0938-5

Aunola, K., Sorkkila, M. ve Tolvanen, A. (2020). Validity of the Finnish version of the Parental Burnout Assessment (ABT). Scandinavian Journal of Psychology, 61(5), 714-722. https://doi.org/10.1111/sjop.12654

Aycan, Z. ve Eskin, M. (2005). Relative Contributions of Childcare, Spousal Support, and Organizational Support in Reducing Work-Family Conflict for Men and Women: The Case of Turkey. Sex Roles, 53(7), 453-471. https://doi.org/10.1007/s11199-005-7134-8

Bayazıt, M. ve Türetgen İ. Ö. (2021). COVID-19 Pandemisinin Gölgesinde Mecburi Evden Çalışma Düzeninin Çalışanların İs-Ev Çatışmaları ve Sağlıklarına Etkisi: Boylamsal Bir Araştırma. (Proje No. 120K365). TÜBİTAK. Tubitak.gov.tr sitesinden 31 Mayıs 2021 tarihinde alınmiştır.

Brownson, K. (2004). The benefits of a work-at-home program. The Health Care Manager, 23(2), 141-144. https://doi.org/10.1097/00126450200404000-00007

Bucciarelli, V., Nasi, M., Bianco, F., Seferovic, J., Ivkovic, V., Gallina, S. ve Mattioli, A. (2021). Depression pandemic and cardiovascular risk in the COVID-19 era and long COVID syndrome: gender makes a difference. Trends In Cardiovascular Medicine. https://doi.org/10.1016/j. tcm.2021.09.009

Busby, D. M., Crane, D. R., Larson, J. H. ve Christensen, C. (1995). A revision of the Dyadic Adjustment Scale for use with distressed and 
nondistressed couples: Construct hierarchy and multidimensional scales. Journal of Marital and Family Therapy, 21(3), 289-308. https://doi. org/10.1111/j.1752-0606.1995.tb00163.x

Busch, M. A., Maske, U. E., Ryl, L., Schlack, R. ve Hapke, U. (2013). Prävalenz von depressiver Symptomatik und diagnostizierter Depression bei Erwachsenen in Deutschland: Ergebnisse der Studie zur Gesundheit Erwachsener in Deutschland In Bundesgesundheitsblatt, Gesundheitsforschung, Gesundheitsschutz, 56(5). https://doi.org/10.1007/ s00103-013-1688-3

Buzzanell, P. M. (2004). Gender in applied communication contexts. Thousand Oaks, California: Sage Publ.

Byrne, B. M. (2016). Structural Equation Modelling with AMOS: Basic Concepts, Applications, and Programming (3rd ed.). New York: Routledge.

Caetano, R., Vaeth, P., Mills, B. ve Canino, G. (2016). Employment Status, Depression, Drinking, and Alcohol Use Disorder in Puerto Rico. Alcoholism: Clinical And Experimental Research, 40(4), 806-815. https:// doi.org/10.1111/acer.13020

Cirhinlioglu, Z., Tepe, Y. K. ve Cirhinlioglu, F. G. (2016). The Relationship between Personality Traits and Marital Quality in Married Couples in Turkey. The Anthropologist, 25(1), 34-44. https://doi.org/10.1080/0 $\underline{9720073.2016 .11892086}$

Coronavirus. (2021). https://www.who.int/health-topics/ coronavirus\#tab=tab 3 sitesinden 27 Ekim 2021 tarihinde alınmıştır.

Creedy, D. K., Sidebotham, M., Gamble, J., Pallant, J. ve Fenwick, J. (2017). Prevalence of burnout, depression, anxiety and stress in Australian midwives: A cross-sectional survey. BMC Pregnancy and Childbirth, 17 (1), 13. https://doi.org/10.1186/s12884-016-1212-5

Crosbie, T. ve Moore, J. (2004). Work-life Balance and Working from Home. Social Policy and Society, 3(3), 223-233. https://doi.org/10.1017/ $\underline{\mathrm{S} 1474746404001733}$

Çiçek, B. ve Almalı, V. (2020). COVID-19 pandemisi sürecinde kaygı özyeterlilik ve psikolojik iyi oluş arasındaki ilişki: özel sektör ve kamu çalışanları karşılaştırması. Turkish Studies, 15(4), 241-260.

Darcy, C. ve McCarthy, A. (2007). Work-family conflict. Journal of European Industrial Training, 31(7), 530-549. https://doi. org/10.1108/03090590710820042

Daza, P., Novy, D. M., Stanley, M. A. ve Averill, P. (2002). The Depression Anxiety Stress Scale-21: Spanish translation and validation with a Hispanic sample. Journal of Psychopathology and Behavioral Assessment, 24(3), 195-205. https://doi.org/10.1023/A:1016014818163 
Dehle, C., Larsen, D. ve Landers, J. (2001). Social Support in Marriage. The American Journal Of Family Therapy, 29(4), 307-324. https://doi. org/10.1080/01926180126500

Dougé, N., Lehman, E. ve McCall-Hosenfeld, J. (2014). Social Support and Employment Status Modify the Effect of Intimate Partner Violence on Depression Symptom Severity in Women: Results from the 2006 Behavioral Risk Factor Surveillance System Survey. Women's Health Issues, 24(4).https://doi.org/10.1016/j.whi.2014.03.006

Du Prel, J. B. ve Peter, R. (2015). Work-family conflict as a mediator in the association between work stress and depressive symptoms: Crosssectional evidence from the German lidA-cohort study. International Archives of Occupational and Environmental Health, 88(3), 359-368. https://doi.org/10.1007/s00420-014-0967-0

Edhborg, M., Matthiesen, A., Lundh, W. ve Widström, A. (2005). Some early indicators for depressive symptoms and bonding 2 months postpartum - a study of new mothers and fathers. Archives Of Women's Mental Health, 8(4), 221-231. https://doi.org/10.1007/s00737-005-0097-5

Evenson, R. J. ve Simon, R. W. (2005). Clarifying the relationship between parenthood and depression. Journal of Health and Social Behavior, 46(4). https://doi.org/10.1177/002214650504600403

Farré, L., Fawaz, Y., Gonzalez, L. ve Graves, J. (2020). How the COVID-19 Lockdown Affected Gender Inequality in Paid and Unpaid Work in Spain. IZA Discussion Papers 13434, Institute of Labor Economics (IZA).

Fowers, B. J. (1991). His and her marriage: A multivariate study of gender and marital satisfaction. In Sex Roles, 24(3), 209-221. https://doi. org/10.1007/BF00288892

Frone, M. R., Russell, M. ve Cooper, M. L. (1992). Antecedents and outcomes of work-family conflict: Testing a model of the work-family interface. Journal of Applied Psychology, 77(1), 65-78. https://doi. org/10.1037/0021-9010.77.1.65

Gager, C. ve Sanchez, L. (2003). Two as One? Journal Of Family Issues, 24(1), 21-50. https://doi.org/10.1177\%2F0192513X02238519

Gaudecker H.M., Radost H., Lena J., Bettina S. ve Christian Z. (2020). Labour Supply in the Early Stages of the COVID-19 Pandemic: Empirical Evidence on Hours, Home Office, and Expectations. IZA Discussion Papers 13158, Institute of Labor Economics (IZA).

Gencer, N. (2020). Covid-19 Sürecinde Yaşlı Olmak: 65 Yaş ve Üstü Vatandaşlar için Uygulanan Sokağa Çıkma Yasağı Üzerine Değerlendirmeler ve Manevi Sosyal Hizmet, Türkiye Sosyal Hizmet Araştırmalar Dergisi, 4(1), 35-42. 
Grandey, A. A. ve Cropanzano, R. (1999). The Conservation of Resources Model Applied to Work-Family Conflict and Strain. Journal of Vocational Behavior, 54(2), 350-370. https://doi.org/10.1006/jvbe.1998.1666

Greenhaus, J. H. ve Beutell, N. J. (1985). Sources of Conflict between Work and Family Roles. The Academy of Management Review, 10(1), 76. https://doi.org/10.2307/258214

Gündoğdu, A. (2007). Relationship Between Self-Construals And Marital Quality (Yayınlanmamış Yüksek Lisans Tezi). Orta Doğu Teknik Üniversitesi, Ankara.

Hao, J., Wang, J., Liu, L., Wu, W. ve Wu, H. (2016). Perceived Organizational Support Impacts on the Associations of Work-Family Conflict or Family-Work Conflict with Depressive Symptoms among Chinese Doctors. International Journal of Environmental Research and Public Health, 13(3), 326-339. https://doi.org/10.3390/ijerph13030326

Henry, J. D. ve Crawford, J. R. (2005). The short-form version of the Depression Anxiety Stress Scales (DASS-21): Construct validity and normative data in a large non-clinical sample. The British Journal of Clinical Psychology, 44(2), 227-239. https://doi.org/10.1348/014466505X29657

Henry, N. J. M., Berg, C. A., Smith, T. W. ve Florsheim, P. (2007). Positive and negative characteristics of marital interaction and their association with marital satisfaction in middle-aged and older couples. Psychology and Aging, 22(3), 428-441. https://doi.org/10.1037/0882$\underline{7974.22 .3 .428}$

Higgins, C. A., Duxbury, L. E. ve Irving, R. H. (1992). Work-family conflict in the dual-career family. Organizational Behavior and Human Decision Processes, 51(1), 51-75. https://doi.org/10.1016/0749-5978(92)90004-Q

Hubert, S. ve Aujoulat, I. (2018). Parental Burnout: When Exhausted Mothers Open Up. Frontiers in Psychology, 9, 1021. https://doi.org/10.3389/ fpsyg.2018.01021

Islam, M. ve Adnan, R. (2017). Socio-Demographic Factors and Their Correlation with the Severity of Major Depressive Disorder: A Population Based Study. World Journal Of Neuroscience, 07(02), 193-202. https:// doi.org/10.4236/wjns.2017.72014

James, S. L., Abate, D., Abate, K. H., Abay, S. M., Abbafati, C., Abbasi, N. ve Murray, C. J. L. (2018). Global, regional, and national incidence, prevalence, and years lived with disability for 354 diseases and injuries for 195 countries and territories, 1990-2017: a systematic analysis for the Global Burden of Disease Study 2017. The Lancet, 392(10159), 1789-1858. https://doi.org/10.1016/S0140-6736(18)32279-7

Jeon, L., Buettner, C. K. ve Grant, A. A. (2018). Early Childhood Teachers' Psychological Well-Being: Exploring Potential Predictors of 
Depression, Stress, and Emotional Exhaustion. Early Education and Development, 29(1), 53-69. https://doi.org/10.1080/10409289.2017.13 $\underline{41806}$

Johnson, M. ve Anderson, J. (2012). The Longitudinal Association of Marital Confidence, Time Spent Together, and Marital Satisfaction. Family Process, 52(2), 244-256. https://doi.org/10.1111/j.15455300.2012.01417.x

Karaköse, S. ve Akçinar, B. (2021). COVID-19 Kapsamında Belirlenen Önleyici Sağlık Davranışları ile İlgili Faktörler. Nesne, 9(21), 619-636. DOI: 10.7816/nesne-09-21-09

Kaya, Y. ve Akın, R. (2021). COVID-19 ile Yaşanan Sosyal İzolasyonun Aile ve Evlilik Yaşamına Yansımaları: Fenomenolojik Bir Çalışma. Turkish Journal Of Family Medicine And Primary Care, 15(3), 510-520. https://doi.org/10.21763/tjfmpc.932521

Kaygısız, A. ve Alkın, T. (1999). Konversiyon bozukluğundaki ruhsal bozukluk eş tanılarının değişkenlerle ilişkisi, Türk Psikiyatri Dergisi, 10(1), 40-49.

Kendler, K. S., Kuhn, J. ve Prescott, C. A. (2004). The interrelationship of neuroticism, sex, and stressful life events in the prediction of episodes of majör depression. The American Journal of Psychiatry, 161(4), 631636. https://doi.org/10.1176/appi.ajp.161.4.631

Kendrick, H. M. ve Drentea, P. (2016). Marital Adjustment. University of Alabama at Birmingham; USA.

Kessler, R. (2003). Epidemiology of women and depression. Journal of Affective Disorders, 74(1), 5-13. https://doi.org/10.1016/S01650327(02)00426-3

Kinderman, P. (2005). A Psychological Model of Mental Disorder. Harvard Review Of Psychiatry, 13(4), 206-217. https://doi. org/10.1080/10673220500243349

Kinderman, P., Schwannauer, M., Pontin, E. ve Tai, S. (2013). Psychological processes mediate the impact of familial risk, social circumstances and life events on mental health. PloS One, 8(10). https://doi.org/10.1371/ journal.pone.0076564

Kockler, M. ve Heun, R. (2002). Gender differences of depressive symptoms in depressed and nondepressed elderly persons. International Journal of Geriatric Psychiatry, 17(1), 65-72. https://doi.org/10.1002/gps.521

Lebert-Charron, A., Dorard, G., Boujut, E. ve Wendland, J. (2018). Maternal Burnout Syndrome: Contextual and Psychological Associated Factors. Frontiers in Psychology, 9, 885. https://doi.org/10.3389/ fpsyg.2018.00885 
Lim, G. Y., Tam, W. W., Lu, Y., Ho, C. S., Zhang, M. W. ve Ho, R. C. (2018). Prevalence of Depression in the Community from 30 Countries between 1994 and 2014. Scientific Reports, 8(1), 2861. https://doi. org/10.1038/s41598-018-21243-x

Lovibond, P. F. ve Lovibond, S. H. (1995). The structure of negative emotional states: Comparison of the Depression Anxiety Stress Scales (DASS) with the Beck Depression and Anxiety Inventories. Behaviour Research and Therapy, 33(3), 335-343. https://doi.org/10.1016/00057967(94)00075-U

Mackinnon, S. P., Sherry, S. B., Antony, M. M., Stewart, S. H., Sherry, D. L. ve Hartling, N. (2012). Caught in a bad romance: Perfectionism, conflict, and depression in romantic relationships. Journal of Family Psychology: JFP: Journal of the Division of Family Psychology of the American Psychological Association, 26(2), 215-225. https://doi. org/10.1037/a0027402

McTernan, W. P., Dollard, M. F., Tuckey, M. R. ve Vandenberg, R. J. (2016). Enhanced Co-Worker Social Support in Isolated Work Groups and Its Mitigating Role on the Work-Family Conflict-Depression Loss Spiral. International Journal of Environmental Research and Public Health, 13(4), 382. https://doi.org/10.3390/ijerph13040382

Mesmer-Magnus, J. R. ve Viswesvaran, C. (2005). Convergence between measures of work-to-family and family-to-work conflict: A meta-analytic examination. Journal of Vocational Behavior, 67(2), 215-232. https:// doi.org/10.1016/j.jvb.2004.05.004

Mikolajczak, M., Brianda, M. E., Avalosse, H. ve Roskam, I. (2018). Consequences of parental burnout: Its specific effect on child neglect and violence. Child Abuse \& Neglect, 80, 134-145. https://doi.org/10.1016/j. chiabu.2018.03.025

Miller, J. R. (2003). Encyclopedia of human ecology. Santa Barbara, Calif., Oxford: ABC-CLIO.

Miller, L. J. (2002). Postpartum depression. JAMA, 287(6), 762-765. https:// doi.org/10.1001/jama.287.6.762

Moscato, B. S., Russell, M., Zielezny, M., Bromet, E., Egri, G., Mudar, P. ve Marshall, J. R. (1997). Gender differences in the relation between depressive symptoms and alcohol problems: A longitudinal perspective. American Journal of Epidemiology, 146(11), 966-974. https://doi. org/10.1093/oxfordjournals.aje.a009224

Muhtz, C., Zyriax, B.-C., Klähn, T., Windler, E. ve Otte, C. (2009). Depressive symptoms and metabolic risk: Effects of cortisol and gender. Psychoneuroendocrinology, 34(7), 1004-1011. https://doi.org/10.1016/j. psyneuen.2009.01.016 
Netemeyer, R. G., Boles, J. S. ve McMurrian, R. (1996). Development and validation of work-family conflict and family-work conflict scales. Journal of Applied Psychology, 81(4), 400-410. https://doi.org/10.1037/0021$\underline{9010.81 .4 .400}$

Noble, R. E. (2005). Depression in women. Metabolism: Clinical and Experimental, 54(5), 49-52. https://doi.org/10.1016/j.metabol.2005.01.014

Nolen-Hoeksema, S. ve Hilt, L. M. (2009). Gender differences in depression. In I. H. Gotlib \& C. L. Hammen (Eds.), Handbook of depression (pp. 386-404). The Guilford Press.

Obidoa, C., Reeves, D., Warren, N., Reisine, S. ve Cherniack, M. (2011). Depression and work family conflict among corrections officers. Journal of Occupational and Environmental Medicine, 53(11), 1294-1301.https:// doi.org/10.1097/JOM.0b013e3182307888

Özgür, G., Atan, S. ve Ardahan, M. (2012). Postpartum depression among working and non-working women in Denizli Turkey, Healthmed, 6(6), 2038-2046.

Perren, S., Wyl, A. von, Bürgin, D., Simoni, H. ve Klitzing, K. von (2005). Depressive symptoms and psychosocial stress across the transition to parenthood: Associations with parental psychopathology and child difficulty. Journal of Psychosomatic Obstetrics and Gynaecology, 26(3), 173-183. https://doi.org/10.1080/01674820400028407

Pietromonaco, P. R. ve Overall, N. C. (2020). Applying relationship science to evaluate how the COVID-19 pandemic may impact couples' relationships. The American Psychologist. Advance online publication. https:// doi.org/10.1037/amp0000714

Proulx, C. M., Helms, H. M. ve Buehler, C. (2007). Marital Quality ve Personal Well-Being: A Meta-Analysis. Journal of Marriage and Family, 69(3), 576-593. https://doi.org/10.1111/j.1741-3737.2007.00393.x

Revati R. D. ve Yogesh A. J. (2012). Mental Health and Depression among Working and Non-Working Women. International Journal of Scientific and Research Publications, 2(8).

Rhee, S. J., Kim, E. Y., Kim, S. H., Lee, H. J., Kim, B., Ha, K. ve Ahn, Y. M. (2014). Subjective depressive symptoms and metabolic syndrome among the general population. Progress in Neuro-Psychopharmacology \& Biological Psychiatry, 54, 223-230. https://doi.org/10.1016/j. pnpbp.2014.06.006

Rich-Edwards, J. W., Kleinman, K., Abrams, A., Harlow, B. L., McLaughlin, T. J., Joffe, H. ve Gillman, M. W. (2006). Sociodemographic predictors of antenatal and postpartum depressive symptoms among women in 
a medical group practice. Journal of epidemiology and community health, 60(3), 221-227. https://doi.org/10.1136/jech.2005.039370

Roehling, R., Moen, R. ve Batt, R. (2003). It's about time: Couples and careers: Spillover. Ithaca, NY: Cornell University Press.

Romanoski, A. J., Folstein, M. F., Nestadt, G., Chahal, R., Merchant, A., Brown, C. H. ve McHugh, P. R. (1992). The epidemiology of psychiatrist-ascertained depression and DSM-III depressive disorders. Results from the Eastern Baltimore Mental Health Survey Clinical Reappraisal. Psychological Medicine, 22(3), 629-655. https://doi.org/10.1017/ $\underline{\mathrm{S} 0033291700038095}$

Roskam, I., Raes, M.E. ve Mikolajczak, M. (2017). Exhausted Parents: Development and Preliminary Validation of the Parental Burnout Inventory. Frontiers in Psychology, 8, 163. https://doi.org/10.3389/ fpsyg.2017.00163

Roskam, I., Brianda, M. ve Mikolajczak, M. (2018). A Step Forward in the Conceptualization and Measurement of Parental Burnout: The Parental Burnout Assessment (PBA). Frontiers In Psychology, 9, 758. https://doi.org/10.3389/fpsyg.2018.00758

Russell-Chapin, L., Chapin, T. ve Sattler, L. (2001). The Relationship of Conflict Resolution Styles and Certain Marital Satisfaction Factors to Marital Distress. The Family Journal, 9(3), 259-264. https://doi. org/10.1177/1066480701093004

Santa Maria, A., Wörfel, F., Wolter, C., Gusy, B., Rotter, M., Stark, S. ve Renneberg, B. (2018). The Role of Job Demands and Job Resources in the Development of Emotional Exhaustion, Depression, and Anxiety Among Police Officers. Police Quarterly, 21(1), 109-134. https://doi. org/10.1177/109861111774395

Santrock, J. W. (2015). Yaşam boyu gelişim. On üçüncü basımdan çeviri. Ankara: Nobel Akademik Yayıncılık.

Sariarslan, H. A., Gulhan, Y. B., Unalan, D., Basturk, M. ve Delibas, S. (2015). The relationship of sleep problems to life quality and depression. Neurosciences (Riyadh, Saudi Arabia), 20(3), 236-242. https://doi. org/10.17712/nsj.2015.3.20150157

Sareen, J., Afifi, T., McMillan, K. ve Asmundson, G. (2011). Relationship Between Household Income and Mental Disorders. Archives Of General Psychiatry, 68(4), 419. doi: 10.1001/archgenpsychiatry.2011.15

Segre, L. S., O'Hara, M. W., Arndt, S. ve Stuart, S. (2007). The prevalence of postpartum depression: The relative significance of three social status indices. Social Psychiatry and Psychiatric Epidemiology, 42(4), 316321. https://doi.org/10.1007/s00127-007-0168-1 
Serhan, N., Ege, E., Ayranc1, U. ve Kosgeroglu, N. (2012). Prevalence of postpartum depression in mothers and fathers and its correlates. Journal Of Clinical Nursing, 22(1-2), 279-284. https://doi.org/10.1111/j.13652702.2012.04281.x

Serin, N. B., Serin, O. ve Özbaş, L. F. (2010). Predicting university students' life satisfaction by their anxiety and depression level. Procedia - Social and Behavioral Sciences, 9, 579-582. https://doi.org/10.1016/j. sbspro.2010.12.200

Spanier, G. B. (1976). Measuring Dyadic Adjustment: New Scales for Assessing the Quality of Marriage and Similar Dyads. Journal of Marriage and the Family, 38(1), 15. https://doi.org/10.2307/350547

St John, P. D. ve Montgomery, P. R. (2009). Marital status, partner satisfaction, and depressive symptoms in older men and women. Canadian Journal of Psychiatry. Revue Canadienne De Psychiatrie, 54(7), 487492. https://doi.org/10.1177/070674370905400710

Stănculescu, E., Roskam, I., Mikolajczak, M., Muntean, A. ve Gurza, A. (2020). Parental burnout in Romania: Validity of the Romanian version of the parental burnout assessment (ABT-RO). New Directions for Child and Adolescent Development, 2020(174), 119-136. https:// doi.org/10.1002/cad.20384

Sullivan, C. (2000). Space and the intersection of work and family in homeworking households. Community, Work \& Family, 3(2), 185-204. https://doi.org/10.1080/713658903

Susi, S., Kumar, K. R. ve Jothikumar, R. (2019). Work-Family Conflict and Depression Among Women Working Professionals. Journal of Computational and Theoretical Nanoscience, 16(2), 745-747. https://doi. org/10.1166/jctn.2019.7802

Szczygieł, D., Sekulowicz, M., Kwiatkowski, P., Roskam, I. ve Mikolajczak, M. (2020). Validation of the Polish version of the Parental Burnout Assessment (PBA). New Directions For Child And Adolescent Development, 2020(174), 137-158. https://doi.org/10.1002/cad.20385

Tavakol, M. ve Dennick, R. (2011). Making sense of Cronbach's alpha. International Journal of Medical Education, 2, 53-55. https://doi. org/10.5116/ijme.4dfb.8dfd

Vignola, R. C. B. ve Tucci, A. M. (2014). Adaptation and validation of the depression, anxiety and stress scale (DASS) to Brazilian Portuguese. Journal of Affective Disorders, 155, 104-109. https://doi.org/10.1016/j. jad.2013.10.031

Westdahl, C., Milan, S., Magriples, U., Kershaw, T. S., Rising, S. S. ve Ickovics, J. R. (2007). Social support and social conflict as predictors 
of prenatal depression. Obstetrics and Gynecology, 110(1), 134-140. https://doi.org/10.1097/01.AOG.0000265352.61822.1b

Whisman, M. A. (2001). The association between depression and marital dissatisfaction, Journal of Social and Personal Relationships. 3-24. https://doi.org/10.1037/10350-001

Whisman, M. A. (2007). Marital distress and DSM-IV psychiatric disorders in a population-based national survey. Journal of Abnormal Psychology, 116(3), 638-643.https://doi.org/10.1037/0021-843X.116.3.638

White, M., Hill, S., McGovern, P., Mills, C. ve Smeaton, D. (2003). 'Highperformance' Management Practices, Working Hours and Work-Life Balance. British Journal of Industrial Relations, 41(2), 175-195. https://doi.org/10.1111/1467-8543.00268

Wolanin, A., Hong, E., Marks, D., Panchoo, K. ve Gross, M. (2016). Prevalence of clinically elevated depressive symptoms in college athletes and differences by gender and sport. British Journal of Sports Medicine, 50(3), 167-171. https://doi.org/10.1136/bjsports-2015-095756

Wood, A. M., Boyce, C. J., Moore, S. C. ve Brown, G. D. A. (2012). An evolutionary based social rank explanation of why low income predicts mental distress: A 17 year cohort study of 30,000 people. Journal of Affective Disorders, 136(3), 882-888.

Wu, M., Chang, C.C. ve Zhuang, W.L. (2010). Relationships of work-family conflict with business and marriage outcomes in Taiwanese copreneurial women. The International Journal of Human Resource Management, 21(5), 742-753. https://doi.org/10.1080/09585191003658912

Yılmaz, Ö., Boz, H. ve Arslan, A. (2017). Depresyon Anksiyete Stres Ölçeğinin (Dass 21) Türkçe Kısa Formunun Geçerlilik-Güvenilirlik Çalışması, Finans Ekonomi ve Sosyal Araştırmalar Dergisi, 2(2), 78-91.

Zhang, H. (2020). The Influence of the Ongoing COVID-19 Pandemic on Family Violence in China. Journal Of Family Violence. https://doi. org/10.1007/s10896-020-00196-8 